\title{
LONE PARENTS AND SOCIAL SECURITY
}

John Hughes*

The domestic purposes benefit for lone parents has been politically charged since its inception. This article examines the developing case law relating to the benefit, with particular reference to the interrelationship between the relevant social security principles and wider issues of family policy.

\section{INTRODUCTION}

The domestic purposes benefit (the DPB) is perhaps the most controversial of all systems of state income support. The origins of the benefit, claims about its alleged effect on behaviour within and outside relationships, and its place within two cultural traditions, have been examined in detail elsewhere. ${ }^{1}$ So, also, has its role within the overall structure of social security in terms of issues such as work-testing. ${ }^{2}$ The aim of this article is to examine the statutory framework and case law surrounding the current conditions of entitlement to the DPB. To the extent that an understanding of that case law depends in part on the history of the benefit, a brief outline of the relevant history is provided by way of background.

\section{BACKGROUND}

By the mid 1960s, the Director-General of what was then the Department of Social Welfare (the DSW) had the discretion to grant an emergency benefit under section 61 of the Social Security Act 1964 (the 1964 Act) on grounds of hardship and personal circumstances. This discretion

* John Hughes is a Senior Lecturer at Canterbury University.

1 See Kay Goodger "Maintaining Sole Parent Families in New Zealand: An Historical Review" (1998) 10 Social Policy Journal of NZ 122, which contains an exhaustive and lucid analysis of the research.

2 Kay Goodger and Peter Larose "Changing Expectations: Sole Parents and Employment in New Zealand" (1999) 12 Social Policy Journal of NZ 53; Moira Wilson "The Policy Response to the Employment Task Force and Changing Patterns of Domestic Purposes Benefit Receipt" (2000) 14 Social Policy Journal of NZ 78; Kay Goodger "Recent Trends in the Employment Rate of Sole Mothers in New Zealand" (2001) 16 Social Policy Journal of NZ 191 
remains available to the chief executive (the chief executive) of the Ministry of Social Development (the MSD). ${ }^{3}$ By 1968 the number of parents bringing up children by themselves had increased. This increase was due, in part, to the increasing incidence of divorce and separation and enhanced statutory recognition of de facto breakdown of legal marriages and, ${ }^{4}$ in part, to an increasing tendency amongst single pregnant women to give birth outside marriage. ${ }^{5}$ In 1968 the DSW decided to place in one group emergency benefits which were payable to women who qualified for emergency benefit under section 61 and who were not being supported by their partners. Internally, the DSW referred to these "grouped" benefits as domestic purposes benefits. In order to qualify for the "administrative" domestic purposes benefit, as a category of emergency benefit, the person concerned had to have taken maintenance proceedings against her partner or against the father of her child(ren). ${ }^{6}$

In 1972 the Royal Commission of Inquiry into Social Security (the McCarthy Commission) ${ }^{7}$ recommended that one statutory benefit should embrace all "solo" parents, ${ }^{8}$ replacing the diverse provisions which then existed in respect of those who fell into three categories. These were, first, the various categories of solo parent; second, women caring at home for a sick or infirm person; and, third, women whose previous domestic commitments had affected (or were deemed to have affected) their ability to obtain employment. Whilst the Commission focussed on solo parents, the position of the second and third groups was considered to be closely analogous. The McCarthy Commission noted that solo parents and their families faced a higher risk of poverty. Its recommendations were explicitly based on the assumption that most married women were financially dependent and that male economic support of the family was still the norm. ${ }^{9}$

The Commission had intended assimilating widows with dependent children along with other categories of solo parents but this was not carried through into the legislation. The widows' benefit remained intact and more generous than the new statutory domestic purposes benefit. The reasons

3 Although decisions of this nature are invariably delegated to front line staff, technically the chief executive remains the decision-maker under the Social Security Act 1964. For this reason, subsequent references will be to the chief executive as opposed to the Ministry.

4 See generally Roderick Phillips Divorce in New Zealand: A Social History (Oxford University Press, Auckland, 1981) ch 2.

5 Goodger, above n 1, 130.

6 Goodger, above n 1, 130.

7 Report of the Royal Commission of Inquiry into Social Security in New Zealand (Government Printer, Wellington, 1972).

8 Since the statute uses the term "solo" it will be used in this article, rather than the preferred contemporary expression, in context, of a "lone" parent.

9 Report of the Royal Commission of Inquiry into Social Security in New Zealand, above n 7, 241-242. 
for this are obscure, but the Royal Commission on Social Policy suggested that the retention of a separate widows' benefit appeared to reflect a value judgment that solo parenthood arising from death of a partner gave rise to a stronger claim than solo parenthood which was "social or partly voluntary" (the underlying assumption being that only the former arose from circumstances beyond the control of the parent). ${ }^{10}$

\section{THE INTRODUCTION OF A STATUTORY DOMESTIC PURPOSES BENEFIT}

The statutory domestic purposes benefit (the DPB) was implemented by the Social Security Amendment Act 1973. As had been the case with the emergency benefit, in order to qualify for the new benefit as a solo parent, applicants were required (where appropriate) to have finalised satisfactory maintenance arrangements for themselves and for their children. ${ }^{11}$ Where an applicant was unable to meet the requirements of the legislation, and was therefore not entitled to receive the statutory benefit, payment continued to be made by way of an emergency benefit at a lower rate. ${ }^{12}$

The number of applications for the new benefit exceeded the Government's expectations by a considerable margin, leading to the establishing of a Domestic Purposes Benefit Committee of Review. ${ }^{13}$ The Review Committee recommended that the benefit should be paid at a reduced rate for up to six months, initially, and that any benefit payment should be of an interim nature with its sole purpose being to avoid hardship, especially for the children. ${ }^{14}$ This reasoning was underpinned by the perception that the availability of financial support outside marriage was contributing to the termination of relationships which might otherwise have continued. A

10 Report of the Royal Commission on Social Policy (Government Printer, Wellington, 1988).

11 For the other categories of domestic purposes beneficiary under ss 27C and 27G of the 1964 Act, see John Black, Stephen Harrop and John Hughes Income Support Law and Practice (Butterworths, Wellington, 1996) paras 1027C.2 and following and 1027G.2 and following.

12 For a summary of the system then in operation, see "Report of the Domestic Purposes Benefit Review Committee" [1977] II AJHR E 28. This requirement existed until the introduction of the liable parent contribution scheme in 1981. Under the new scheme, the solo parent was required simply to identify the liable parent "in law", upon which the Director-General of the DSW took over responsibility for the relevant proceedings. This approach continues under the child support scheme, discussed below.

13 "Report of the Domestic Purposes Benefit Review Committee", above n 12. Chaired by a magistrate, Mr Jack Horn (later an Arbitration Court judge), the Committee was criticised as lacking any social science expertise or significant input from the Department of Social Welfare, see Brian Easton Pragmatism and Progress (University of Canterbury Press, Christchurch, 1981) ch 9.

14 "Report of the Domestic Purposes Benefit Review Committee", above n 12, 48-49. 
secondary theme was that the DPB also provided an incentive for single women to keep their children rather than having them adopted. ${ }^{15}$

Although it was argued cogently at the time that the Review Committee had relied on defective statistical interpretation in its analysis, ${ }^{16}$ the Government adopted this recommendation and the resulting interim benefit was called emergency maintenance allowance. Payment was made in terms of the emergency provisions contained in section 61 at a rate $\$ 16$ a week less than the appropriate maximum rate of domestic purposes benefit. This remained the case until December 1985, when the rate of the emergency maintenance allowance was altered to a rate equivalent to that of the statutory DPB. The DSW, in reporting to the Royal Commission on Social Policy in 1988, later concluded - in contrast to the assumptions underlying the Review Committee's report that there was no sound research-based evidence one way or the other about the effect of the DPB on incentives to separate. ${ }^{17}$

Finally, the balance between childcare responsibilities and work had lain at the root of the McCarthy Commission's recommendation that a statutory domestic purposes benefit be created. The benefit was designed to ameliorate need where a solo parent was left "to provide singlehandedly both financial and parental support for dependent children". ${ }^{18}$ Sole responsibilities for support were seen to limit the opportunity to earn an adequate income. The Royal Commission examined paid work in this context in terms of the beneficiary's freedom to work, where possible, and the consequent abatement effect of earnings. ${ }^{19}$ When the issue was next examined officially, by the 1987 Benefit Task Force, whilst the effect of earned income on benefit rates was again a focus, the Task Force favoured positive promotion of work and some neutralisation of assistance over work-tested limitations on access to social security. A range of "self-help" initiatives aimed at encouraging entry to the full-time paid labour force were canvassed, most notably good quality child care. ${ }^{20} \mathrm{~A}$ year later, the Royal Commission on Social Policy noted simply that the Department of Social Welfare's 1987 Briefing Papers restated that the aim of the domestic purposes benefit was "to provide income support for people whose domestic responsibilities preclude them from full time paid employment and who are otherwise unsupported". ${ }^{21}$

15 "Report of the Domestic Purposes Benefit Review Committee", above n 12, ch 2.

16 Analysis cited in Goodger, above n 1, 136-138.

17 See generally Goodger, above n 1, 138 and following.

18 Report of the Royal Commission of Inquiry into Social Security in New Zealand, above n 7, 242.

19 Report of the Royal Commission of Inquiry into Social Security in New Zealand, above n 7, 246-250.

20 New Zealand Government Benefit Reform: the Next Steps (New Zealand Government, Wellington, 1987).

21 Report of the Royal Commission on Social Policy, above n 10, vol III, part 2, 498. For a summary of research on the issue between 1987 and 1998, see the suite of background papers released as Documents on DPB/WB Reform (Ministry of Social Development, Wellington, 2001). 
This approach was radically revised in 1991, as one part of the sweeping restrictions on access to social security introduced under the policy document Social Assistance: Welfare that Works. ${ }^{22}$ The National Government of the day proposed regrouping the existing six categorical benefits into three groups - unemployed, health related, and solo parents. ${ }^{23}$ It was then proposed that these groups would be streamed into "fully work ready", "work ready - part time" and "fully work exempt". Only DPB recipients with young children needing substantial home care were anticipated as falling into the third category. No substantive change was proposed to the basic structure of the DPB. The ensuing changes were, rather, a reduction in the rate of benefit payable, in common with other benefits, ${ }^{24}$ and a rise in the minimum age of entitlement from 16 to $18 .^{25}$

There was, however, a new focus on work-testing, ${ }^{26}$ which was part of a wider campaign on the issue of "welfare dependency". ${ }^{27}$ By 1996, the departmental focus on recipients of the DPB had shifted from promotion of work, where possible, to concern that New Zealand had "a high and increasing proportion of families headed by a sole parent and a low proportion of sole parents employed either part- or full-time". ${ }^{28}$ As from 1 April 1997, the "reciprocal obligations" of the recipients of the DPB were extended. ${ }^{29}$ An applicant for a domestic purposes benefit had to be willing to undertake part-time work and must have taken reasonable steps to obtain part-time work where the youngest dependent child was aged 14 years or older. If the youngest child was between

22 Social Assistance: Welfare that Works (Government Printer, Wellington, 1991). For the broad context, see Jonathon Boston and Paul Dalziel (eds) The Decent Society? Essays in Response to National's Economic and Social Policies (Oxford University Press, Auckland, 1992); Brian Roper and Chris Rudd (eds) State and Economy in New Zealand (Oxford University Press, Auckland, 1993); Jonathon Boston, Paul Dalziel and Susan St John (eds) Redesigning the Welfare State in New Zealand (Oxford University Press, Auckland 1999); Jane Kelsey Rolling Back the State (Bridget Williams Books, Wellington, 1993); Jane Kelsey The New Zealand Experiment (Auckland University Press, Auckland, 1995); Margaret McClure A Civilised Community (Auckland University Press, Auckland, 1998) ch 6.

23 In addition, there was to be a "small group category" for domiciliary care of invalids and widows/women alone.

24 See Boston and Dalziel, above n 22, chs 5 and 6.

25 See Part V MINIMUM AGE QUALIFICATION.

26 See Jane Higgins "From Welfare to Workfare", in Boston, Dalziel and St John, above n 22, ch 14.

27 For the policy context, see Higgins, above n 26; M Levine, H Wyn and L Asiasiga Lone Parents and Paid Work: A Study of Employment Patterns and Barriers and Options for Change (Social Policy Agency Evaluation Unit, Wellington, 1993) and the papers collected in the symposium Beyond Dependency (1997) 8 Social Policy Journal of NZ. On the vexed concept of "dependency" generally, see the contrasting analyses in David Schmidtz and Robert E Goodin Social Welfare and Individual Responsibility (Cambridge University Press, Cambridge, 1998) ch 2.2 .

28 Department of Social Welfare Post-Election Briefing Paper: Strategic Directions (Department of Social Welfare, Wellington 1996) 77.

29 The rationale for imposing the work-testing regime on lone parents is presaged in Post-Election Briefing Paper: Strategic Directions, above n 28. 
the ages of 6 and 14, the applicant had to be willing to undertake (and must have taken reasonable steps to obtain) part-time work. It was a condition of receiving a DPB that the applicant complied with a request to attend mandatory interviews, ${ }^{30}$ and - if she or he was a work-tested beneficiary that the applicant complied with the work test. ${ }^{31}$ These provisions did not apply if the applicant was granted an exemption from the work test. ${ }^{32}$ Exemption could be granted where the person concerned was the principal caregiver of a dependent child with special needs, whose welfare would be unduly harmed if the person attended employment and training and for whom satisfactory alternative care arrangements were not available or are unable to be made by the person. ${ }^{33}$ An exemption could also be granted, amongst other things, where the beneficiary had started to live apart from her or his spouse within the previous six months (a provision designed to allow time to recover from the trauma of the circumstances surrounding separation). ${ }^{34}$

The work test was then abolished in $2001,{ }^{35}$ in favour of facilitation into employment through case management. The new provisions - and their policy origins - are outlined later, as one aspect of examining current entitlement to the DPB.

\section{SOLO PARENTS}

Under section 27B(1) of the Social Security Act 1964, the following applicants can qualify for the DPB as solo parents, subject to certain conditions:

(a) A woman who is the mother of one or more dependent children and who is living apart from, and has lost the support of, or is being inadequately maintained by, her husband:

(b) An unmarried woman who is the mother of one or more dependent children:

(c) A woman whose marriage has been dissolved by divorce and who is the mother of one or more dependent children:

30 Under what was then section 60HA of the Social Security Act 1964.

31 Social Security Act 1964, s 27(2B).

32 Social Security Act 1964, s 27 (2)(c). The exemption arose under the Social Security (Exemptions from Mandatory Interviews and Work Tests) Regulations 1996.

33 "Special needs" were defined in the Social Security (Exemptions from Mandatory Interviews and Work Tests) Regulations 1996 in terms of a physical or intellectual disability, a medical condition, a chronic or recurring illness, or a learning or behavioural difficulty.

34 Social Security (Exemptions from Mandatory Interviews and Work Tests) Regulations 1996.

35 Social Security Amendment Act 2001. 
(e) A woman who is the mother of one or more dependent children and who has lost the regular support of her husband because he is subject to a sentence of imprisonment and is-

(i) serving the sentence in a penal institution; or

(ii) subject to release conditions or detention conditions (as those terms are defined in section 4(1) of the Parole Act 2002) that prevent him undertaking employment:

(f) A man who is the father of one or more dependent children whose mother is dead or who for any other reason are not being cared for by their mother.

A solo parent within one of these categories is eligible for a domestic purposes benefit so long as they can meet three further general qualifications in section $27 \mathrm{~B}(2) .{ }^{36}$ Under subsection (2), first, the applicant must either be (or have been) legally married or be at least 18 years old. Second, the applicant must be caring for a dependent child or children. Third, the applicant must not be living together with her husband, his wife, or with the other parent of the child, as the case may be, whether in a legal or a "de facto" marriage.

With one exception, the general qualifications under subsection (2) will be examined before turning to the various categories of solo parent. ${ }^{37}$

\section{MINIMUM AGE QUALIFICATION}

Under the MSD's operational policy, ${ }^{38}$ no social security benefit is payable to pregnant women or solo parents under the age of $16 .^{39}$ The woman's parents are expected to provide full support.

36 Subject to other provisions of the Social Security Act 1964 governing matters such as residency, and so forth See generally Bill Atkin "Social Security Law" in International Encyclopaedia of Laws (Kluwer International, The Hague, 1996) ["Social Security Law"]; Black, Harrop and Hughes, above n 11; The Laws of New Zealand (Butterworths, Wellington, 1994) Social Security.

37 The exception is the requirement that the applicant not be living together with her husband or his wife, or with the other parent of the child, as the case may be. This is discussed substantively below in Part VII A Unmarried Women.

38 The operational policy of the MSD is contained on an intranet Manuals and Procedures system (MAP), in which benefits are divided by category but no further conventional referencing features (such as paragraph numbers) are incorporated into the text. Unless otherwise noted, the subsequent references to this operational policy are under the heading "Domestic Purposes Benefit" on MAP. The MAP references are derived from a CD-ROM containing the guidelines, which is distributed by the MSD to community organizations and updated periodically. The policy cited is that provided as being current as at 1 November 2004.

39 At first sight, this blanket rule might arguably be seen as an unlawful fetter on the statutory discretion to grant an emergency benefit. Section 61 of the Social Security Act 1964, which provides for emergency benefits, provides for eligibility in terms of any person who is by reason of age, or of physical disability, or of domestic circumstances, or for any other reason unable to earn a livelihood and who is not qualified for any other benefit (emphasis added). It is probably the case, however, that the proper use of discretion would operate against 
Essentially, under the policy, there is no intervention unless there is a perceived "care and protection" issue. The parents of the young woman might qualify for supplementary benefits, such as the special benefit, however, in relation to additional living costs. ${ }^{40}$

Until 1991 the minimum age of entitlement for a DPB was 16. The age of eligibility was raised to 18 in 1991 after political criticism of the accessibility of the DPB to young women. ${ }^{41}$ Between the ages of 16 and 18, an unmarried pregnant woman may be entitled to a sickness benefit on grounds of hardship. ${ }^{42}$ Once the child has been born, a woman in this age group will qualify for a DPB if she has been legally married. If not, an emergency benefit may be granted on grounds of hardship under section 61 of the 1964 Act to an applicant who is aged 16 or 17 years, who is living at home and who is either pregnant or a solo parent, where her parents are unable to support her. ${ }^{43}$

granting an emergency benefit on the basis that the age limit under section $27 \mathrm{~B}(2)$ of the Social Security Act 1964 would then effectively be circumvented. By analogy, see SSAA Decision No 35/87 (24 April 1987) SSA 85/86 and SSAA Decision No 14/99 (2 March 1999) SSA 120/98.

40 The special benefit is paid under section $61 \mathrm{G}$ of the Social Security Act 1964. It is described in greater detail below. See generally "Social Security Law", above n 36; Black, Harrop and Hughes, above n 11; and The Laws of New Zealand Social Security, above n 36. From 1 April 2006, the special benefit will be replaced with a less flexible provision of temporary additional support under a substituted section $61 \mathrm{G}$, see Social Security (Working for Families) Amendment Act 2004, s 10.

41 Social Security Amendment Act (No 2) 1991, s 4. For the political background, see Kelsey The New Zealand Experiment, above $\mathrm{n} 22,280-283$. Much of the criticism was based on the belief that pregnancy in the teenage years was a "lifestyle choice". See for example David G Green From Welfare State to Civil Society (Wellington, New Zealand Business Roundtable, 1996) 132: "[G]irls contemplating the possibility of pregnancy are aware that the result will be a subsidised house and an income to match earnings from employment without the trouble of working". New Zealand research suggests that a major risk factor for adolescent pregnancy is, rather, living in a seriously disadvantaged family with major discord between parents, Judith Davey "Gender Differences and Adolescent Risks" (2000) 14 Social Policy Journal of NZ 130, with other factors including subjection to physical punishment after the age of 12 and isolation from peer confidantes research by the Otago Medical School summarised in Fiona Cassie "Loneliness is Close to Motherliness" NZ Education Review (9 April 1997). See also Roy Nash "Teenage Pregnancy: Barriers to an Integrated Model for Policy Research" (2001) 17 Social Policy Journal of NZ 200.

42 Social Security Act 1964, s 54A(2).

43 Defined for general purposes in terms of the parent's income only being sufficient to qualify for the receipt of family support under the Income Tax Act 1996: Office of the Minister of Social Services Work and Income, Ministerial Direction, "Grants of Emergency Benefits" (6 October 1998) cl 6. The resulting emergency benefit is then classed administratively as an emergency maintenance allowance. The operational policy provides, however, that each case must be decided on its own facts in order to determine whether the applicant will suffer hardship unless an emergency benefit is granted (for the operational policy, see generally n 38 ). For some implications of this recent shift to assumed family support, see Mervyl McPherson "Extended Family Support, the State and Policy: Assumptions, Attitudes and Actualities" (1999) 12 Social Policy Journal of NZ 139. 
Operational policy where the applicant is aged 16 or 17 years and is living away from home, requires that it be "unreasonable to expect the client to live at home or be supported by [her] parents" before an emergency benefit is granted. ${ }^{44}$ The existing policy includes, as examples, cases where the parents' home is too small and overcrowded to accommodate the woman and her baby, or where it is "better for the client's physical, mental or emotional health or well-being to live away from home". 45

\section{CARING FOR ONE OR MORE DEPENDENT CHILDREN}

The combination of subsections (1) and (2) of section 27B is that the applicant for DPB must have one or more "dependent" children for whom she or he is caring. ${ }^{46}$ "Dependency" is then defined in section 3 of the 1964 Act in terms of a child who meets four cumulative criteria. First, the child must be one whose care is primarily the responsibility of that person. Second, the child must be being maintained as a member of that person's family. Third, the child must be financially dependent on that person. ${ }^{47}$ Fourth, the child must not be a child in respect of whom payments are being made by virtue of residence in foster homes or iwi care. ${ }^{48}$

The 1964 Act does not define the phrase "caring for the child". As a rule of thumb, if the applicant and the child were living together, under operational policy guidelines the MSD assumes that the applicant was caring for the child. Where the child was not living with the applicant, a

44 See $n 38$.

45 This is assumed in cases of family breakdown because of violence or sexual abuse that can be confirmed by a relevant professional agency. In other cases, a family meeting is held. The operational guidelines state that no emergency benefit is to be granted if the client "lives away from home of their own choice or [there is] no serious breakdown in the family relationship". These are similar guidelines in relation to family breakdown to those established in relation to the independent youth benefit under section $60 \mathrm{~F}$ of the 1964 Act. That benefit is specifically aimed at applicants who are 16 or 17 years of age: see "Social Security Law", above n 36; Black, Harrop and Hughes, above n 11; and The Laws of New Zealand Social Security, above n 37. The issue apparently remains to be considered in the light of research establishing that risk factors for adolescent pregnancy include family dysfunction: see $\mathrm{n} 41$.

46 A "child" for this purpose is an unmarried person under the age of 18 years, other than a person who is aged 16 or 17 years and financially independent: Social Security Act 1964, s 3.

47 Financial dependence was held to exist where the child was a casual worker but feared that he might lose his employment at any time or receive an insufficient income to be financially independent. In this context the Social Security Appeal Authority looked for a pattern of working which established financial independence: SSAA Decision No 12/96 (16 February 1996) SSA 152/95.

48 This being "[a] child in respect of whom payments are being made under section 363 of the Children, Young Persons, and Their Families Act 1989 - but, for the purposes of [Schedule 3, Schedules 6, 8, and 9, Schedule 16, and Schedules 17 and 18], does not include a child in respect of whom an orphan's benefit or an unsupported child's benefit is being paid." For the orphan's benefit and unsupported child's benefit, see "Social Security Law", above n 36; Black, Harrop and Hughes, above n 11; The Laws of New Zealand Social Security, above $\mathrm{n} 36$. 
major factor is how permanent or temporary the arrangement is, and what has precipitated the child being cared for by someone else. ${ }^{49}$

The cumulative nature of the criteria is illustrated by the finding in SSAA Decision No $152 / 02,{ }^{50}$ in which the Social Security Appeal Authority (the Appeal Authority) concluded that "[for] a child to be a dependent child, it is clear that a child must not only be financially maintained by her parent but the parent must be the child's primary caregiver". In that case, where the child's grandmother (with whom the appellant had lived) was held to be the person who had primary responsibility for day-to-day care, and to whom the child was bonded and turned for her needs, there was held to be no qualifying dependency on the appellant during the period in question. Similarly, the definition of "dependent child" has been held to exclude, as relevant caregivers, those whose effective day-to-day contact is governed by access orders, as opposed to custody orders, in relation to their children. ${ }^{51}$ Against this, given the cumulative criteria, the decision that dependency exists is not determined simply by reference to the fact that one parent has legal custody, where the other parent in fact has the primary responsibility for day to day care. $^{52}$

Where the child being claimed for is not the natural or adoptive child of the applicant, the chief executive has the discretion under section 27A(3) of the 1964 Act to regard the child as the applicant's child and the applicant as being the mother or father of that child. The condition is that the child is being maintained by the applicant and was at any time maintained by the husband or wife of the applicant. ${ }^{53}$ The child will then qualify the caregiver as an applicant for the DPB in terms of section 27B. The most common example arises where a couple have assumed responsibility for the care of a relative's child at birth and have maintained the child for some time prior to separating. In SSAA Decision No $132 / 2000,{ }^{54}$ the child in question was placed with the appellant and her husband by the Department of Child Youth and Family Services (CYFS) and she received board payments from that Department. When the couple separated, the appellant was denied a domestic purposes benefit on the basis that she was not "maintaining" the child because financial maintenance came from CYFS in the form of board payments. On this point, the Appeal

49 This provision commonly covers children in special schools, psychiatric institutions, and so forth. For the guidelines, see n 38 .

50 SSAA Decision No 152/02 (27 November 2002) SSA 136/02

51 SSAA Decision No 31/93 (19 March 1993) SSA 160/92. For the relevant High Court decision, see D $v E$ (1988) 5 NZFLR 65, 70.

52 SSAA Decision No 138/01 (26 September 2001) SSA 201/00.

53 It should be emphasised that the conditions are cumulative - there is a requirement for current maintenance and previous maintenance by the applicant's partner.

54 SSAA Decision No 132/2000 (6 October 2000) SSA 130/00. 
Authority held that the "maintenance" envisaged by section 3 of the 1964 Act entails feeding, clothing and sheltering the child and providing "all of the other kinds of nourishment (emotional and physical) that young children require". The financial assistance from CYFS alone was held not to provide maintenance in this sense. The Department was held to have elected to interpret its financial obligations to her in an unduly narrow and restrictive way, particularly since CYFS had encouraged the appellant to apply for custody and guardianship.

Under section $80 \mathrm{BD}(6)$ of the 1964 Act, where a person receiving a DPB or widow's benefit stops caring for a dependent child "because of a sudden change of circumstances which was beyond the beneficiary's control", the benefit ends eight weeks later. The extended period is to allow the beneficiary to adjust to a lower rate of benefit after the DPB is cancelled. ${ }^{55}$ In $S S A A$ Decision No $044 / 02,{ }^{56}$ the reference to a sudden change of circumstances was held clearly to cover the case of a non-custodial parent failing to return a child after a holiday access period (rejecting what might seem an extraordinary argument by the chief executive that the effective "continuing care" by the non-custodial parent after the holiday, but in breach of agreement, could not be described as being "sudden"). 57

\section{THE CATEGORIES OF ELIGIBLE SOLO PARENTS}

We can turn now to the separate categories of solo parents in section 27B(1) of the 1964 Act. These categories, as currently enacted, have remained essentially undisturbed since 1973 and heavily reflect the thinking of the McCarthy Commission. As at November 2004, however, proposals for "neutral" laws governing relationships (whether married, de facto, or same sex) have led to the introduction of the Relationships (Statutory References) Bill 2004 as an accompanying measure to the Civil Union Act 2004. Both measures - and particularly the decision to recognise same sex civil unions - have proved to be highly controversial. The former, if enacted in its introductory form, will affect some aspects of categorisation under section $27 \mathrm{~B}$, in ways that will be outlined briefly following discussion of the current law.

\section{A Unmarried Women}

Under paragraph (b) of section $27 \mathrm{~B}(1)$, an applicant can qualify if she is an unmarried woman who is the mother of one or more dependent children. Whilst section 27(1) lists separately under paragraph (c) a mother of one or more dependent children whose marriage has been dissolved by divorce, such a woman is, of course, also "unmarried" and the separate categorisation appears to be

55 As opposed to the general cancellation provision, which becomes operative on a date no later than the pay day after entitlement ceases: Social Security Act 1964, s 80BD(1).

56 SSAA Decision No 044/02 (21 May 2002) SSA 264/2001.

57 The eight week period was held to run from the date the non-custodial parent applied to have the child included in her benefit. 
an historical anomaly. ${ }^{58}$ For social security purposes, the treatment of women falling within either category is effectively identical.

In order to qualify for the DPB under any of the categories of solo parenthood, nevertheless, under section 27B(2) the applicant must not be "living together" with a husband, wife, or the other parent of the dependent child. ${ }^{59}$ In a legal marriage, for social security purposes, "living together" is simply the opposite of "living apart", the latter being one criterion of entitlement under section 27B(1). ${ }^{60}$ The concept of "living together" with a husband or wife is not restricted to legal marriage, however. "Husband"' for the purposes of section 27B includes a man with whom a woman has entered into a "relationship in the nature of marriage" although not legally married to him and "wife" has a corresponding meaning. ${ }^{61}$ The Appeal Authority has held that a finding that parents of a dependent child are "living together" under section $27 \mathrm{~B}(2)$, so as to disqualify an applicant from entitlement, does not necessarily depend on a concurrent finding that they are living in a relationship in the nature of marriage with one another. ${ }^{62}$ Most cases, however, turn on an allegation that such a relationship exists, and the relevant legal test for establishing the relationship then becomes crucial.

In Ruka $v$ Department of Social Welfare $(R u k a),{ }^{63}$ the Court of Appeal held that no relationship in the nature of marriage exists in the absence of financial interdependence and mutual emotional commitment. ${ }^{64}$ In the key passage of the joint judgment of Richardson $\mathrm{P}$ and Blanchard J, with which Thomas J concurred, ${ }^{65}$ the Judges stated that: ${ }^{66}$

58 The McCarthy Commission, had treated "divorced women" as being distinct from "unmarried mothers", based on existing classification under the deserted wives' benefit and the administrative categories of the emergency benefit: Report of the Royal Commission of Inquiry into Social Security in New Zealand, above n 7, 247.

59 This provision was inserted only in 1987, in order to deal with "recently discovered" uncertainty as to whether a solo parent could receive the DPB once remarried or living in a de facto relationship: Hon Ann Hercus, Minister of Social Welfare (18 March 1987) 479 NZPD 7849

60 See Part VII B Women "Living Apart" from their Husbands

61 Social Security Act 1964, s 27A(1).

62 SSAA Decision No 002/04 (16 January 2004) SSA 171/03. The result, if correct, would be to impose a lower threshold for disentitlement in cases where the applicant's husband or wife was also the parent of a relevant dependent child. In the decision itself, however, the parties lived in the same home with a degree of pooling of finances and household responsibilities, including childcare.

63 Ruka v Department of Social Welfare [1997] 1 NZLR 154 (CA)

64 The Court was considering the issue under section 63(b) of the Social Security Act 1964, which enables the chief executive to treat an unmarried couple as being married where they have entered into such a relationship. See John Hughes, "Battered Women's Syndrome and 'Interdependence' as Factors in Establishing Conjugal Status in Social Security Law" (1999) 7 Waikato LR 104.

65 Ruka v Department of Social Welfare, above n 63, 185 Thomas J. 
In our view a relationship in the nature of marriage for the purpose of the Social Security Act is one in which an essential element is that there is an acceptance by one partner that (to take the stereotypical role) he will support the other partner and any child or children of the relationship if she has no income of her own or to the extent that it is or becomes inadequate. The commitment must go beyond mere sharing of living expenses, as platonic flatmates or siblings living together may do; it must amount to a willingness to support, if the need exists. There must be at least that degree of financial engagement or understanding between the couple. ...

Where financial support is available nevertheless there will not be a relationship in the nature of marriage for this purpose unless that support is accompanied by sufficient features evidencing a continuing emotional commitment not arising just from a blood relationship. Of these, the sharing of the same roof and of a sexual relationship (especially if it produces offspring) are likely to be the most significant indicators.

The expression "relationship in the nature of marriage" necessarily requires a comparison with a legal marriage but that is not a straightforward exercise. ${ }^{67} \ldots$ The comparison must seek to identify whether there exist in the relationship of two unmarried persons those key positive features which are to be found in most legal marriages which have not broken down (cohabitation and a degree of companionship demonstrating an emotional commitment). Where these are found together with financial interdependence there will be such a merging of lives as equates for the purposes of the legislation to a legal marriage.

Although it was not necessary for the decision, the majority stated obiter that the presence of extreme violence over the relevant period - as had occurred in the case before them - could affect the question whether the parties were living in a relationship in the nature of marriage.

In its subsequent decision, $R v$ Batt, ${ }^{68}$ the Court held that "obviously a willingness to provide support is a state of mind to be inferred from the relationship overall" and as "an inference drawn from the inter-dependence of the relationship itself". In Ray v Department of Social Welfare, ${ }^{69}$ payment of "board" representing most of the alleged partner's benefit to the appellant, with whom he was living in an "emotionally committed" relationship, was held to be evidence of financial interdependence. Whilst there have been a number of Appeal Authority decisions concerning the

66 Adding that, "It will not, however, be negated by a refusal to support, or an arrangement that support will not be given, which is motivated by the knowledge that the dependent partner will then be able to claim a benefit. Such a stratagem cannot create a genuine absence of support." Ruka v Department of Social Welfare, above n 63 , 161-162 Richardson P and Blanchard J.

67 Adding that "[furthermore], it is not to be thought that because certain negative features (such as physical abuse, lack of emotional commitment) are found in some de jure marriages, the same factors in a relationship between a man and a woman who are not married are to be disregarded in determining whether that relationship is in the nature of a marriage". Ruka v Department of Social Welfare, above n 63, 162 Richardson P and Blanchard J.

$68 \quad R v$ Batt (3 August 2000) CA 47/00.

69 Ray v Department of Social Welfare (15 March 2000) HC WN AP 326/96. 
issue since Ruka, all turn on their individual facts and none advance the underlying analysis beyond that set out in the original judgment.

The decision in Ruka was concerned with whether the appellant had "entered into" a relationship in the nature of marriage. Whether the concept of "living together" in such a relationship under subsection 2(c) of section 27B(1) adds anything to the statutory disqualification, once the relationship itself has been entered into, remains open to argument. In Director-General of Social Welfare $v W^{70}$ for example, McGechan J suggested obiter that the reference to a married couple "living apart" in paragraph (a) of subsection (1) might require "spatial separation". It might be argued that since "living together" is the opposite of "living apart", a concept in which such physical separation has generally been seen to be a necessary component,${ }^{71}$ then "living together" necessarily connotes an absence of physical separation and particularly separate living accommodation. In essence, "living together" might be seen to require the alleged couple to have gone one stage further than "entering into" the relationship so as to share accommodation. ${ }^{72}$ This would be consistent with the approach to statutory interpretation that avoids, where possible, the imputation that Parliament has used redundant words. ${ }^{73}$ It would also be consistent, arguably, with the rationale for the more beneficial rate of the DPB, as compared with other benefits available to single people, the DPB being designed in part to meet the additional costs of setting up and maintaining a home. ${ }^{74}$ On the other hand, it could be argued from the statutory history that the words "living together", taken alone, do not connote the sharing of one household, in the sense of living together under one roof. The concept of a relationship in the nature of marriage replaced an earlier statutory concept of "living together on a domestic basis as husband and wife" specifically to exclude this possibility, the emphasis at that stage being on the removal of the phrase "on a domestic basis" rather than the words "living together". ${ }^{75}$ Further, it might be argued that the

70 Director-General of Social Welfare v W[1997] 2 NZLR 104 (HC).

71 See Part VII B Women "Living Apart" from their Husbands.

72 In SSAA Decision No 002/04, above n 62, living in the same home "with a degree of pooling of financial resources and household responsibilities including child care" was held to be sufficient for it to be found that the parents of a child were living together.

73 J F Burrows Statute Law in New Zealand (3 ed, LexisNexis, Wellington, 1999) 201 and following.

74 Ministerial Task Force on Income Maintenance Benefit Reform: Resource Book (Department of Social Welfare, Wellington, 1986).

75 Social Security Amendment Act (No 2) 1978. See John Hughes "Domestic Purposes Benefit: Lessons from the Furmage Case" [1979] NZLJ 32. Whilst in Ruka v Department of Social Welfare, above n 63, 169 Richardson P and Blanchard J (with whom Thomas J concurred) stated that "since the amendment to section 63 in 1978, the sharing of a household is not essential". The Court was there considering the concept of "entering into" a relationship in the nature of marriage. 
conventional legal test for "living together" may now be less demanding ${ }^{76}$ in any event, than the Ruka test for the existence of a relationship in the nature of marriage, outlined above.

\section{B Women "Living Apart" from their Husbands}

Under paragraph (a) of section $27 \mathrm{~B}(1)$, an applicant can qualify if she "is the mother of one or more dependent children" and is "living apart from, and has lost the support of or is being inadequately maintained by, her husband". ${ }^{77}$ At this point the interplay of section $27 \mathrm{~A}$ and section $27 \mathrm{~B}$ is potentially confusing, reflecting a series of ad hoc drafting amendments since 1973, coupled with shifting case law perceptions of what constitutes a "de facto" marriage.

The confusion arises because a woman with a husband under section 27B(1)(a) is juxtaposed in the drafting with an "unmarried woman" under section $27 \mathrm{~B}(1)(\mathrm{b})$, whilst - as we have seen "husband" is now defined to include a man with whom a woman has entered into a relationship in the nature of marriage. It seems arguable, notwithstanding the extended definition of "husband", and the approach in some decisions of the Social Security Appeal Authority, ${ }^{78}$ that the original intention of the drafter was to restrict the criteria of "living apart" and "loss of support" in para (a) to cases where the only putative disqualifying relationship is with a man to whom the woman is legally married. First, paragraph (a) refers both to "living apart" and to "inadequate maintenance", each being a concept that is associated with legal marriage. ${ }^{79}$ Second, as we have just seen, case law developments around the definition of a relationship in the nature of marriage rule out such a relationship where the parties are not financially interdependent (for example, where no support is forthcoming and no such obligation is accepted), thus seeming to render the extended definition of "husband" redundant in this context. Third, and arguably by strong analogy, in a comparatively late amendment to section 3 of the 1964 Act "sole parent" has been defined for other purposes to mean: ${ }^{80}$

... a person who is the principal caregiver in respect of a dependent child and who is -

76 See Part VII B Women "Living Apart" from their Husbands.

77 It has been held that, on appeal, the onus lies on the chief executive to establish that the alleged couple are not living apart: SSAA Decision No 86/2000 (10 July 2000) SSA 175/99.

78 See for example: SSAA Decision No 51/84 (25 June 1984) SSA 169/83; SSAA Decision No 86/84,(29 November 1984) SSA 4/84; and SSAA Decision No 32/87 (10 April 1986) SSA 8/86.

79 "Living apart" features as a criterion related to legal marriage in section 63(a) of the Social Security Act 1969 and a right to "maintenance" (for the adult partner) is a concept singularly associated with legal marriage. For example, in Ruka v Department of Social Welfare, above n 63, 169-170 Richardson P and Blanchard J held that "[a] simple balancing of equivalent features is not possible because for married persons financial obligations are not voluntary: the dependent spouse has some right to maintenance".

80 Inserted by section 2(1) of the Social Security Amendment Act (No 2) 1990, as part of an amendment extending coverage of the liable parent contribution scheme to sole parents receiving social security benefits other than the DPB. 
legally married but living apart from his or her spouse; or

not legally married -

and not living in a relationship in the nature of marriage.

For a woman who remains married, then, arguably the nature of the test to be applied will vary, depending on the identity of her purported partner. Where a woman remains legally married and otherwise entitled to a DPB under paragraph (a), by virtue of "living apart" from (and remaining unsupported by) her "legal" husband, living together in a relationship in the nature of marriage with a man to whom she is not married will then rule out entitlement under subsection (2)(c) of section 27B. Despite a number of decisions in which the test for a "relationship in the nature of marriage" has been applied to legally married couples by the Appeal Authority, ${ }^{81}$ and the District Court, ${ }^{82}$ it is clear that this is an inappropriate analysis. ${ }^{83}$ Conversely, it is suggested that the Appeal Authority has also fallen into error in cases where it has applied the "living apart" criterion to alleged relationships in the nature of marriage. ${ }^{84}$

What, then, is meant by "living apart" under paragraph (a) of subsection (1)? The leading decision is Excell $v$ Department of Social Welfare (Excell). ${ }^{85}$ Excell was an appeal against conviction for social security fraud and the facts were unusual. The appellant had been convicted of breaching section 127 of the 1964 Act by wilfully omitting to inform the Department that she had resumed cohabitation with her husband, thereby rendering him ineligible for the DPB (which he had been receiving whilst she was imprisoned). ${ }^{86}$ Fisher $\mathrm{J}$ held that the District Court Judge had found against the appellant on what he described as the "critical factual question" of whether the appellant and her husband lived together under the same roof and that, to this extent, the appeal was based upon misunderstanding.

In case he was wrong on this point, Fisher J went on to analyse the concept of "living apart" under section $27 \mathrm{~B}$. Three key principles were advanced as to what constitutes "living together". ${ }^{87}$

81 See for example: SSAA Decision No 102/94 (31 October 1994) SSA 112/94; SSAA Decision No 99/95 (28 September 1995) SSA 171/94.

82 For example, see the District Court decisions quoted in SSAA Decision No 35/2000 (15 March 2000) SSAA 158/99; and in Excell v Department of Social Welfare [1991] NZFLR 241 (HC).

83 Excell v Department of Social Welfare, above n 82, Fisher J.

84 See, for example, SSAA Decision No 51/84 (1984) 5 NZAR 331 and SSAA Decision No 164/03 (10 October 2003) SSA 103/01, para 44.

85 Excell v Department of Social Welfare, above $\mathrm{n} 82$.

86 It is unclear from the decision why the appellant, and not her husband, was prosecuted.

87 Illustrating the confused history of cohabitation issues in social security, and despite Fisher J's clear statement that his analysis in Excell v Department of Social Welfare was analytically distinct from the required approach 
First, according to Fisher J, in order to be living together there must be some form of mental commitment to live together as husband and wife and a manifestation of that commitment by conduct (with inferences as to intention being drawn from conduct in cases of doubt). Second, the conduct is concerned with an aggregation of factors rather than with one single factor - "[it] is the cumulative quality, quantity, continuity and duration of these factors that matters". Examples advanced in Excell included the sharing of accommodation, pooling of financial resources, the sharing of a sexual relationship, joint leisure and social activities, the sharing of parental obligations and "presentation to outsiders" as a couple. In determining this issue, Fisher J noted that the courts have applied conventional family law principles as to cohabitation in this context. ${ }^{88}$ Third, it was easier to establish that a legally married couple are living together than to demonstrate that an unmarried couple are living in a relationship in the nature of marriage, given that "[a] legally married husband and wife have a duty to cohabit", so that cohabitation is seen to cease only where one party intends to repudiate "the obligations inherent in the marriage relationship" and manifest that intention by conduct. On this basis, Fisher J suggested that "[in] a legal marriage it is a very short step from physical proximity to an assumption of continued or renewed cohabitation, especially if the alleged cohabitation has not been preceded by any lengthy separation and where there are other ties such as children in common".

As with other case law under the 1964 Act, Fisher J relied on the family law principle, ${ }^{89}$ that "living apart" involves the two cumulative ingredients of physical separation and a mental attitude averse to cohabitation on the part of one or both parties. Two points must then be made at the outset. First, the phrase "living apart" appears also in section 63(a) of the 1964 Act, which confers a discretion on the chief executive to regard legally married couples as "living apart" for the purpose of assessing entitlement to any social security benefit. Whilst the principles developed under section 63(a) have often simply been transplanted directly into consideration of the issue under section 27B, in Director-General of Social Welfare $v W^{90}$ McGechan $\mathrm{J}$ noted that the weight to be attached to the phrase differed as between the two sections and that "[each] is to be

to identifying a relationship in the nature of marriage, the Excell $v$ Department of Social Welfare principles later came to be applied by the Department of Social Welfare in identifying such relationships, under the generic title "Judge Fisher's rules". See Frances Joychild Report to the Minister for Social Services: Review of Department of Work and Income Implementation of the Court of Appeal Decision Ruka v Department of Social Welfare [1997] 1 NZLR 154 (18 June 2001) 34-35. See the approach described in Bill Atkin, Living Together Without Marriage (Wellington, Butterworths, 1991) [Living Together without Marriage] para 4.2; Black, Harrop and Hughes, above n 11, para 1063.13.

88 These echo the earlier list advanced by Davison CJ in Edwards v Edwards (1979) 2 MPC 51 (SC) (a matrimonial property case).

89 Established in Sullivan v Sullivan [1958] NZLR 912 (CA).

90 Director-General of Social Welfare $v$ W, above n 70; applied in $R v$ Creeks (23 June 2004) CA 26/04 (an appeal against conviction for benefit fraud). 
focused upon in its own right". ${ }^{91}$ Second, there is the uncertain impact of the majority approach in $R u k a$, which McGechan $\mathrm{J}$ described as containing an "interpretative orientation towards financial needs warranted by the legislation" or a "needs-oriented construction". ${ }^{92}$ It is suggested that these observations require that some considerable caution be exercised when examining the earlier case law on "living apart" under section 27B, including Excell. That case law, whilst consistent, almost invariably treated findings under the two sections as interchangeable and was not informed by the profound interpretative shift represented by Ruka. A brief survey of the case law can now be attempted.

The main area of difficulty lay, and continues to lie, in the weight attached to the "external indicators" from which inferences of emotional commitment are drawn, which - once present negate the criterion of "living apart". ${ }^{93}$ Under existing policy guidelines applied by the chief executive, ${ }^{94}$ it can be generally accepted that the parties are living apart when they occupy separate homes and where it is clear that the marriage relationship no longer exists. On the issue of physical - or "spatial" - separation, the guidelines inform staff that if a couple who are legally married are clearly shown to be residing in the same place it will be difficult, though not impossible, for them to substantiate a claim that they are "living apart". ${ }^{95}$ In SSAA Decision No $86 / 84,{ }^{96}$ the Appeal Authority did note obiter that it would not lay down a principle that whenever a husband and wife continue to occupy the matrimonial home after a dispute they cannot in some circumstances be said to be living apart, adding that "[quite] obviously there are situations where this can and does happen ... ". ${ }^{97}$ This possibility was further constrained, however, in SSAA

91 Director-General of Social Welfare $v W$, above n 70, 108 McGechan J.

92 Director-General of Social Welfare $v W$, above $n$ 70. In the case of Director General of Social Welfare $v W$, which turned on the effect of an enforced separation (where the parties did not desire the marriage to end) for the purposes of the Social Security Act 1964, s 63(a), the Ruka approach to construction was held to be irrelevant.

93 Until the Court of Appeal clarified the test for identifying a "relationship in the nature of marriage" in Ruka $v$ Department of Social Welfare, above n 63, this had been a major difficulty with the courts' approach to identifying "de facto" relationships under s 63(b) of the Social Security Act 1964. Significantly, perhaps, the difficulties in the pre-Ruka case law had themselves resulted in part from the tendency for some courts to apply an "indicator list", developed to determine whether legally married were indeed "living apart", to the different question whether unmarried people had entered into a relationship in the nature of marriage. See $n 87$.

94 See n 38

95 There may be an undeveloped analogy with cases under section 39 of the Family Proceedings Act 1980, where the term "living apart" appears and the Courts have sometimes held that people living under the same roof are nevertheless living apart for the purposes of section 39. See the argument in $R v$ Creeks, above $\mathrm{n} 90$.

96 SSA Decision No 86/84 (29 November 1984) SSA 4/84.

97 In this case, however, the Appeal Authority held that the parties were not physically living apart where they still continued to occupy the same accommodation (the matrimonial home). Nor was the mental element satisfied, since neither party was held to be averse to a resumption of the relationship, although they were neither sleeping together nor speaking to each other on a regular basis. See also Social Security Appeal Authority Decision No 
Decision No 73/99, ${ }^{98}$ in which a differently constituted Appeal Authority required as what it described as a "threshold" that the woman be a "virtual prisoner" of the man before it would apply this exception. It is suggested, however, that this gloss on the concept of "physical separation" is both unwarranted, in terms of the case law, and unsafe.

In relation to "emotional separation" as an aspect of "living apart" under section 27B, where the parties are not living permanently at the same location, the chief executive's operational guidelines direct staff to indicators used for unmarried people in determining a relationship in the nature of marriage. 99 "Living apart" connotes separation due not simply to external circumstances, but to an emotional severance in the relationship. ${ }^{100}$ Consistently with this, the Appeal Authority has frequently held that the appellant's claim to have "unilaterally repudiated" the obligation of marriage during the relevant period has to be tempered by "outward indicators" that the parties were not emotionally separated. ${ }^{101}$ Particularly relevant to the DPB, there appears to be some element of risk in organising daily affairs closely, to deal with continuing needs of children,

56/01 (16 May 2001) SSA 271/2000, a decision under section 63(a) of the Social Security Act 1964, where the parties had lived in the same premises for some time but, whilst the marriage had been a "relatively unhappy one" from an early stage, the only indicator of either party trying to remove themselves from the marriage was the appellant's decision to move to a separate bedroom. In Director-General of Social Welfare v Taru (6 May 1997) HC WN AP 334/94, where the couple effectively lived separate lives within the same house, and had followed legal advice in not notifying the Department, the High Court implicitly upheld the Appeal Authority's decision that the couple were not living apart but agreed that their reliance on advice was sufficient to preclude a requirement that the respondent repay the benefit under section 86 of the Social Security Act 1964 . SSAA Decision No 73/99 (30 July 1999) SSA 6/99.

99 See n 38.

100 See for example, SSAA Decision No 68/2000 (24 May 2000) SSA 215/99 (husband seafarer who spent long periods away); SSAA Decision No 152/02, above n 50 (couple lived separately for periods while wife cared for sick mother); SSAA Decision No 070/2004 (23 June 2004) SSA 115/03 (appellant and her husband physically separated whilst she obtained treatment for a mental health condition). In each case, the couple were held not to have been living apart. Contrast the finding that a couple were "living apart" in SSAA Decision No 011/04 (20 February 2004) SSA 110/03, in which the appellant suffered from schizophrenia and her husband had been physically separated from her (and living overseas) for 10 months, having lived separately - but under the same roof - for some years before that.

101 See, for example, SSAA Decision No 68/2000, above n 100 (where the appellant had actively supported her husband's application for permanent residence); SSAA Decision No 35/2000, above n 82 (where children had been born to the couple during the period of alleged estrangement); SSAA Decision No 86/2000, above n 79; SSAA Decision No 059/03 (21 May 2003) SSA 137/02. On unusual facts in SSAA Decision No 19/98 (April 1997) SSA 138/97, the Appeal Authority even held that an alleged "sham" marriage, involving a legal ceremony, following which the parties lived together for a period, debarred the appellant from the DPB for the period in question. Contrast SSAA Decision No 048/04 (April 2004) SSA 020/03, where a sham marriage was entered into in order to support an immigration application for the husband and the couple were not physically living together at the relevant time. 
particularly where separation is essentially amicable, even where the parties are physically separate. ${ }^{102}$

One means of establishing that one of the parties has mentally accepted that the marriage, as an emotional bond, is over, notwithstanding some external indicators to the contrary, is by pointing to a court order relating to domestic protection. In SSAA Decision No 87/84, ${ }^{103}$ the Appeal Authority held that the continuing existence of a maintenance order and a non-molestation order against the appellant's husband indicated a mental attitude averse to cohabitation despite his continued visits to the appellant's house. In two cases where the parties had continued to live under the same roof in unhappy circumstances for a period of time, co-habitation was said to have ceased only when a protection order was obtained. ${ }^{104}$

It might be inferred from these decisions that the date of the court order provided a convenient point in time from which the necessary degree of emotional separation could be established, notwithstanding other - less tangible - evidence of the duration of domestic violence. In some decisions, however, the Appeal Authority has come close to requiring some court order as evidence of an assertion that the appellant regarded the marriage as being at an end. ${ }^{105}$ Since then the chief executive has argued more bluntly, in SSAA Decision No $062 / 03,{ }^{106}$ that violence is simply not a relevant factor in assessing whether a married couple are "living apart". Although this argument was not expressly adopted by the Appeal Authority, the appellant was held not to have been "living apart" from her husband, notwithstanding that she had feared for her physical safety during

102 See for example, SSAA Decision No 059/03, above n 101. All such decisions, however, involve an amalgam of factual considerations, of which this is only one. Given the recognised needs of children for contact subsequent to parental separation (see the research cited at $\mathrm{n} \mathrm{173)}$ ) it seems strongly arguable that corresponding caution should be exercised in the weight attached to this criterion in determining the nature of the relationship between the adults.

103 SSAA Decision No 87/84 (29 November 1984) SSA 30/84.

104 SSAA Decision No 73/99, above n 98, and SSAA Decision No 56/01 (16 May 2001) SSA 271/2000.

105 See for example, SSAA Decision No 135/01 (26 September 2001) SSA 333/2000. Noting that the appellant had not "found it necessary to obtain a domestic protection order against her husband", the Authority went so far as to suggest that "the submission that the appellant did not have the emotional strength to disassociate herself from involvement with her husband is in a sense an admission that the appellant has not distanced herself from the emotional bond of the marriage". Similarly, in SSAA Decision No 063/02 (23 May 2002) SSA 169/01 the Authority accepted that the appellant was assaulted by her husband on more than one occasion but emphasised that she had not sought a non-molestation order. In both cases, however, as in others, the Appeal Authority also found that evidence of lack of financial support was not credible. See also SSAA Decision No 070/2004, above $\mathrm{n} 100$, in which - against a background of alleged abuse and physical violence - the Authority emphasised that no "decisive action to leave the family home" had been taken prior to an application for a domestic violence order.

106 SSAA Decision No 062/03 (21 May 2003) SSA 243/02. 
intermittent periods when they shared a household (amongst other things he had chased her with an axe, punched her, and assaulted their school age daughter).

Most of the decisions where violence has been established, but has not led to a finding of "living apart", have then led to overpayments being established against the appellant under section 86 of the 1964 Act. ${ }^{107}$ The chief executive's operational guidelines accept that there may be an entitlement to an emergency benefit (paid as an emergency maintenance allowance) ${ }^{108}$ where a client is experiencing violence from a partner with whom she is still living. ${ }^{109}$ Inexplicably, however, none of the Appeal Authority decisions upholding overpayments in cases where violence has been established has considered the possible application of the established principle of "notional entitlement" so as to reduce the relevant debt by the amount that might have been received by way of an emergency benefit during the relevant period. ${ }^{110}$

It is to be noted that the parties must not only be living apart under paragraph (a) of section 27B(1). There must also be a loss of support. In SSAA Decision No 135/97, ${ }^{111}$ the Appeal Authority emphasised the significance of financial support in determining whether there had been a "loss of support" within the meaning of the section. In SSAA Decision No 33/93, ${ }^{112}$ where the parties had separated physically, but continued (amongst other things) to operate a joint bank

107 Social Security Act 1964, s 86 enables the chief executive to recover benefit payments that have been made in excess of the relevant legal entitlement. See "Social Security Law", above n 36; Black, Harrop and Hughes, above $\mathrm{n} 11$; and The Laws of New Zealand Social Security, above n 36.

108 See $\mathrm{n} 38$.

109 Once the woman concerned is in receipt of an emergency maintenance allowance, the guidelines state that there should be a reference to an appropriate agency with a view to seeking a resolution of the abuse. Clause 15.2 of the Special Needs Grants Programme, approved under section 124(1)(d) of the Social Security Act 1964 provides for recoverable and non-recoverable grants if a sole parent is relocating with the assistance of a social service agency after experiencing family violence. See generally the MAP guidelines, above n 38 , under "Special Needs Grants".

110 Under the concept of notional entitlement, the amount of any debt to be recovered under section 86 of the Social Security Act 1964 may be reduced in appropriate cases by an amount equivalent to any other benefit, grant or allowance to which the beneficiary might have been entitled during the relevant period, see Moody $v$ Chief Executive, Department of Work and Income [2001] NZAR 608 (HC). It is suggested that the Chief Executive should bear the responsibility for raising this as a possibility on appeal, even if only for the purpose of explaining why notional entitlement was not applied to the debt. Notional entitlement was applied to a violent relationship in SSAA Decision No 063/02, above n 105, but only so as to reduce the overall debt by discounting several periods where the appellant had left her violent husband to live separately. The principle was also applied to a domestic purposes benefit to which the appellant was not entitled in Appellant (70/2000) $v$ Department of Work and Income [2000] NZAR 541 (SSAA), off-setting the debt by half the married rate of what was then the community wage.

111 SSAA Decision 135/97 (17 December 1997) SSA 117/97.

112 SSAA Decision No 33/93 (25 March 1993) SSA 51/93. 
account the Appeal Authority held that "[it] may well be that the parties were living apart but their lives were still sufficiently merged to the point that neither had yet fully lost the support of the other."

It has been suggested, above, that the existing categories of entitlement to the DPB represent essentially arbitrary divisions, based upon historical factors at the time of its introduction. The existence of a separate set of principles to be used when establishing eligibility for married and unmarried women respectively is one example. There seems no reason in principle why the same test - that developed by the Court of Appeal in Ruka - should not be applied to both situations. "Living apart", under paragraph (a) of subsection (1) overlaps with the concept of lack of emotional commitment and "not being supported" overlaps with that of financial interdependence. Indeed, as we have seen, to some extent treating both categories in the same way would reflect operational reality. ${ }^{113}$ An argument for having one test apply to both categories might also be seen to arise from the recent changes marked by the Property (Relationships) Act 2001. ${ }^{114}$ There is also legislative precedent arising from the abortive attempt to introduce a universal benefit in 1990. At this time, draft legislation set out common criteria to apply whether establishing a relationship in the nature of marriage or deciding whether two legally married people were living apart. ${ }^{115}$

Finally, a decision that an applicant qualifies under paragraph (a) has obvious implications for the other parent under the child support scheme. These implications are outside the scope of this article. ${ }^{116}$

\section{Women whose Husbands are Imprisoned}

The remaining category of female solo parents who may be eligible for the DPB, subject to complying with subsection (1) of section 27B, consists of women who have lost the regular support of their husbands as a result of the husband's imprisonment. There is no case law under this provision as such, probably because the only discrete legal issue - imprisonment - is subject to data-matching between the relevant government agencies.

113 See n 95.

114 A point made obiter by the Court of Appeal in $R v$ Creeks, above $\mathrm{n} 90$ which concerned an appeal against conviction for social security fraud, based on failure to disclose that the appellant was not living apart from her husband whilst claiming a single person's benefit.

115 Social Welfare (No 2) Bill 1990, cl 2(3). The criteria then listed in cl 2(3) reflected the "indicator" list approach later found wanting in Ruka v Department of Social Welfare, above n 63. For a contemporary analysis, see Living Together Without Marriage, above n 87, 58-59.

116 The alleged father has no right of review or appeal against the grant of a DPB, such rights being restricted to applicants or beneficiaries affected by the relevant decision: Social Security Act 1964, ss 10A and 12J. For the Child Support Act 1991, see Dick Webb and others (eds) Family Law in New Zealand (vol 1, 10 ed, Butterworths, Wellington, 2001) 339 and following; Peter J Trapski and others, Trapski's Family Law (vol 5, Brookers, Wellington, 1991) "Child Support". 


\section{Men whose Dependent Children are not being Cared for by their Mother}

When it was suggested to the McCarthy Commission that male solo parents should be provided with the same benefit entitlements as their female counterparts, the Commission had responded that the cases were not the same. Men were seen as more easily able to obtain a full time job and as "less trained to care for the home and children than are most women and ... less prepared to undertake those responsibilities". ${ }^{117}$ The Commission had concluded, nevertheless, that men should be eligible for the same benefit as women where "the interests of all concerned [are] best met by the father staying at home and caring for the children, at least until suitable alternative arrangements can be made ... ". ${ }^{118}$

As a result, a man may qualify for the DPB only on the ground that he is the father of one or more dependent children whose mother is dead or who for any other reason are not being cared for by their mother. Reflecting the views of the McCarthy Commission, these are far more restrictive criteria than those that apply to women solo parents. A man must show that the dependent child is not being cared for by her or his mother, whereas women applicants under the other gateways to entitlement need only show that they themselves are not being adequately supported by the other parent of the child. ${ }^{119}$

It is not possible for a man to argue successfully that joint custody or shared custody can lead to qualification under the rubric "any other reason". This is because sections 27BA and section 70B of the 1964 Act, taken together, ensure that only one parent can qualify for a DPB in such circumstances. ${ }^{120}$ There is no definition of "cared for" in the context of the mother's relationship with the children but, in SSAA Decision No 40/92, ${ }^{121}$ the Appeal Authority held that where the appellant's wife - whilst notionally separated from the appellant - cooked and cleaned for the appellant and their dependent children on a regular basis after working on a night shift and thus "continue[d] to be reasonably fully involved in the care of their dependent children", the appellant could not be said to be a man whose children were not being "cared for" by their mother.

117 Report of the Royal Commission of Inquiry into Social Security in New Zealand, above n 7, 249.

118 Report of the Royal Commission of Inquiry into Social Security in New Zealand, above n 7, 249.

119 SSAA Decision No 33/94 (17 May 1994) SSA 167/93 which concerned an arrangement where the woman was the primary caregiver was held to rule out DPB for the man. In SSAA Decision No 036/04 (undated) SSA 061/03, the Appeal Authority emphasised that for a child to be a dependent child, she or he must not only be financially maintained by the parent, but the parent must be the child's primary caregiver. Whilst the appellant was closely involved in childcare on a regular basis, the Appeal Authority emphasised the interim custody order obtained by his wife.

120 See Part IX EFFECT OF CUSTODY.

121 SSAA Decision No 40/92 (14 May 1992) SSA 7/92. 


\section{E The Relationships (Statutory References) Bill 2004}

The above categories will be amended if the Relationships (Statutory References) Bill 2004 passes into law. The introductory note to this bill outlines the governmental objective of having "neutral" laws covering what are described as "committed, exclusive and stable relationships". ${ }^{122}$ It is intended that the same legal rights and responsibilities will apply to married, de facto (whether opposite or same sex), and civil union relationships, as envisaged by the accompanying Civil Union Bill 2004. The wider issues posed by these pieces of legislation are outside the scope of this article.

The intended consequential amendments to the Social Security Act 1964, however, will have a significant impact on the categories of solo parent that have just been examined. First, the 1964 Act is amended to treat persons in civil unions on the same basis as persons who are married. ${ }^{123}$ Second, a definition of "de facto relationship" is inserted into the Act. This definition is intended to reflect the case law on the concept of relationships in the nature of marriage, outlined above. ${ }^{124}$ In contrast to the current restriction of such relationships to those between partners of the opposite sex, however, the new concept of a "de facto relationship" will apply to relationships between a woman and a man, a woman and a woman, or a man and a man. The main consequences for the domestic purposes benefit are two-fold. First, those persons in a civil union relationship will be treated in the same way as section $27 \mathrm{~B}$ currently treats legal marriages. ${ }^{125}$ Second, persons who are in opposite-sex de facto relationships will be treated for benefit purposes in the same way as

122 Relationships (Statutory References) Bill 2004, no 151-1 explanatory note, 1.

123 Relationships (Statutory References) Bill 2004, no 151-1 sch 8.

124 Relationships (Statutory References) Bill 2004, no 151-1 explanatory note, 8. As currently drafted in Schedule 9 of the Bill this goal seems not to be met when considering whether two people "live together as a couple", see proposed section $3 \mathrm{~B}(1)$, defining a "de facto relationship". For example, under the new test, the couple must be willing to support one another financially (and any child of the relationship) if the need exists and simply be "committed to each other emotionally", see proposed section $3 \mathrm{~B}(3)$. The $R u k a$ test, outlined above, requires, at least, evidence of continuing emotional commitment in addition to financial interdependence, see Part VII A Unmarried Women. Further, in determining whether two people are living together as a couple, the new test then resorts to the check-list approach found wanting in Ruka (proposed section 3B(4)) and leaves the decisionmaker free to attach any weight to any item on the checklist that seems appropriate (proposed section $3 \mathrm{~B}(5)$ ).

125 So that the dissolution of a civil union has the same effect on benefit entitlement as the dissolution of a marriage, see proposed paragraph (c) to s 27B(1) in Schedule 9. The new drafting retains the current - but now modified - distinction between a "single woman" who is the mother of one or more children, under proposed paragraph (a) to subsection (1) and a "woman whose marriage or civil union has been dissolved", under proposed paragraph (b) to subsection (1). A woman "whose de facto relationship has ended" is then added to the latter category in paragraph (b). The current application of this distinction is criticised above, in the commentary to note 113 and following. 
married persons. ${ }^{126}$ Incidental changes to the law governing what are currently relationships in the nature of marriage include a codification of some aspects of current administrative policy, under which a facilitation period may be allowed before treating a couple as having entered into a de facto relationship for benefit purposes, ${ }^{127}$ and a requirement for parental consent before recognising a de facto relationship involving a person younger that 18 years. ${ }^{128}$

\section{REDUCTION OF BENEFIT}

The McCarthy Commission had concluded that: ${ }^{129}$

[Although] the State's responsibility must be recognised and discharged even though the primary responsibility rests upon and is being evaded by the applicant's husband or the father of the children, the applicant for a benefit should be expected to co-operate in a reasonable action to enforce the primary responsibility.

Originally the DPB provisions required that the father or mother of each dependent child be identified in law before a grant of a DPB could be made. As we have seen, failure to do so meant that the applicant could only qualify for an emergency maintenance allowance (EMA) at a lower rate. This requirement was withdrawn, and substituted by what is now section 70A of the 1964 Act, in $1987 .{ }^{130}$ As at November 2004, significant amendments to section 70A are proposed in the Social Security (Social Assistance) Amendment Bill 2004. These will be discussed separately, following discussion of the current law.

Section 70A applies, by virtue of subsection (1), where certain benefits (including a DPB) are being paid to a solo parent and the beneficiary has failed or refused to identify in law the other parent of the relevant child, or failed to name the other parent as a liable parent or to testify in child support proceedings. Under subsection (2), the weekly rate of benefit is then reduced by

126 This change is intended to take effect as from 1 April 2007, Relationships (Statutory References) Bill 2004, no 151-1, sch 9 .

127 Proposed s 3C in the Relationships (Statutory References) Bill 2004, no 151-1, sch 9.

128 Or alternatively, on application, consent by the Family Court, see proposed section $3 \mathrm{~B}(2)$ in the Relationships (Statutory References) Bill 2004, sch 9. Any rules made under section 16A of the Family Courts Act 1980 will apply to such applications, under proposed section 3B(2) in the Relationships (Statutory References) Bill 2004, no $151-1$, sch 9 .

129 Report of the Royal Commission of Inquiry into Social Security in New Zealand, above n 7, 259. This general issue of primary responsibility was dealt with at chapter 35 of the McCarthy Report.

130 Social Security Amendment Act 1987. 
\$22. ${ }^{131}$ The policy rationale is to provide an incentive to beneficiaries who care for dependent children to ensure that the other parent complies with their child support contributions. ${ }^{132}$

There are three exceptions under section 70A(3), which apply at the discretion of the chief executive. These arise where there is insufficient evidence to establish who is in law the other parent; or the beneficiary is taking active steps to identify who is in law the other parent; or the child was conceived as the result of sexual violation or incest. ${ }^{133}$ Under subsection (4), the reduction ceases to apply to a beneficiary who subsequently carries out the necessary steps under subsection (2). According to the Appeal Authority, "[this] suggests that the deduction should be lifted when or at the point in time that the Chief Executive is satisfied that the beneficiary falls within one of the exemptions provided for". ${ }^{134}$ In practice, under operational guidelines, the benefit is initially granted at the maximum rate. If it becomes apparent that the other parent of the child will not be identified in law and the person receiving the benefit does not fall within one of the three exceptions outlined above, the benefit is reduced. ${ }^{135}$

\section{A Insufficient Evidence to Establish Parental Identity}

The first exception under section $70 \mathrm{~A}(3)$, that there is insufficient evidence to establish who is, in law, the other parent, is self-explanatory. Although there appears to be no case law on the point, it would seem a logical inference that this exception will only arise in cases where the chief executive is satisfied that active steps either have been taken to identify the other parent, but inconclusively, or that such steps will not resolve the issue and cannot realistically be expected.

\section{B Identification in Law}

The second exception arises where the beneficiary is taking active steps to identify who is, in law, the other parent. The meaning of the phrase "identify in law" was considered in $R v$ Chief Executive of the Department for Work and Income. ${ }^{136}$

131 The amount equivalent to the maximum amount of family support payable for a second or subsequent child.

132 Hon Ann Hercus, Minister of Social Welfare (18 March 1987) 479 NZPD 7849. For the child support scheme, see $\mathrm{n} 116$.

133 In relation to the third exception, the current operational guidelines instruct staff that proof is not required, police reports are not essential, and that - if the client makes such an allegation - "unnecessary detail" is not to be required, see note 38 .

134 SSAA Decision No 039/03 (4 April 2003) SSA 056/02.

135 The taking of "active steps" is subject to an administrative four week "period of grace" under the guidelines, see n 38 .

$136 R v$ Chief Executive of the Department for Work and Income [2003] 3 NZLR 319 (HC). 
In that case the appellant had named the father of her daughter on an application form for the DPB in June 2000. She had not completed a child support application, because the child's birth had not been registered. The appellant had spoken to the putative father about registering the child's birth, but he had declined to sign the birth guide form. The appellant first contacted her lawyer about the issue in July and then, after a discussion with the father (who had approached her), telephoned her lawyer again in August. Eventually, in late September, a law firm was instructed to take paternity proceedings. The grant of the DPB was subject to the imposition of the $\$ 22$ deduction up to the point where lawyers were first consulted about paternity proceedings.

John Hansen J rejected the appellant's submission that she had met the primary obligation to "identify in law" by naming the father in the application. ${ }^{137}$ Pointing to the policy rationale, the Judge stated that: ${ }^{138}$

... [If] all that was required to 'identify' was the mere naming of a person, then the scope of the requirement in the section would be so limited that other parts of the section would be otiose.

Simply naming a person does not make them a parent 'in law'. There are various ways to establish that a person is a parent 'in law'. In this case, the most obvious ways would be a formal acknowledgement by the father, or the obtaining of a paternity order. Here it was apparent at an early stage that the father was not prepared to make a formal acknowledgement, and, in practical terms, the only other route available to the appellant was to apply for a paternity order.

Simply filling in the name [on the application form] does not satisfy the requirement of the section.

The next issue was whether, nevertheless, the appellant had satisfied the requirement of taking active steps to identify who was "in law" the other parent of her child. John Hansen J rejected an unusual suggestion by the Social Security Appeal Authority that such steps could have been taken even before the child was born. ${ }^{139}$ Nevertheless, the Judge held that, on the facts, the steps taken in the case could not be described as being "active" within the meaning of the provision but rather were "desultory". John Hansen $\mathrm{J}$ added that the taking of active steps must be measured objectively and that "[the] lack of activity by this appellant could not be justified on any reasonable basis". By way of an obiter rule of thumb, it was suggested that, subject to evidence, a period of up to two weeks following the birth was reasonable to allow for a mother to "settle down from that trauma" and that "[following] that, advances should be made to the putative father, and if he

137 An analysis later applied in SSAA Decision 039/03, above n 134.

$138 R v$ Chief Executive of the Department of Work and Income, above n 136, para 16-18 John Hansen J.

139 Noting that "(it) would not infrequently be the case that a father, being confronted with a child on birth, may change a previously held attitude", $R v$ Chief Executive of the Department for Work and Income, above n 136, para 27 John Hansen J. 
denies paternity, and will not formally acknowledge it, a solicitor should be immediately instructed."

Whilst John Hansen $\mathbf{J}$ found that the Appeal Authority had not itself intended to apply a blanket test requiring legal intervention in all cases, it is suggested, with respect, that both the language of the original decision, and earlier practice, indicate that this was indeed likely to have been the Authority's approach. In terms of earlier practice, in SSAA Decision No 93/92, ${ }^{140}$ a reduction following failure to finalise knowledge of paternity through a lawyer was described as the "price to be paid" under section 70A for "taking things slowly". A year later, in SSAA Decision No $113 / 93,{ }^{141}$ the appellant provided the name of her child's father to the chief executive but the father had refused to sign a deed of acknowledgement of paternity and a child support application. The father of the child had previously accepted responsibility for the financial support of the appellant. The appellant cited cultural reasons why she could not take the matter any further. Her whanau would not allow her to communicate with the father of her child nor request written confirmation of paternity from him because there had been a serious breach of protocol - the tribes of the appellant and the father had not met concerning the matter. The Appeal Authority held, amongst other things that "[in] order to obtain her benefit at the full rate she is required, by section $70 \mathrm{~A}$, to take the further steps of either obtaining a paternity order against him or of fulfilling the requirements of the Child Support Act 1991" adding that "[if] she does not wish to take these additional steps or does not feel able to do so then she is, unfortunately, not entitled to the full rate of benefit" (emphasis added). ${ }^{142}$

Underpinning the appeal in $R v$ Chief Executive of the Department for Work and Income's case, as in many social security appeals, was the perception that the Department had fettered its discretion by a fixed policy (in this case a general policy of not accepting that "active steps were being taken until an application was made to a solicitor to take formal legal steps") ${ }^{143}$ and that the Appeal Authority had effectively endorsed this approach in its decision on the facts. John Hansen J

140 SSAA Decision No 93/92 (31 August 1992) SSA 40/92.

141 SSAA Decision No 113/93 (3 November 1993) SSA 103/93.

142 On the cultural issue, the Authority held that "[s 70A] may well result in a process that could be regarded as culturally insensitive, but the appropriate forum for that submission is Parliament, so that the appropriate legislative changes can be made. Neither the Department nor this Authority is in a position to assess the cultural sensitivity of particular provisions of the Social Security Act: the Department's role is to ensure that it makes its decisions in accordance with the provisions of the Act and this Authority's role is similar ....."

143 Under the operational policy (as to which see note 38 ) it seems implicit that any recognised consultation with a lawyer must be with a view to the taking of such formal steps to establish paternity. 
simply commented that, if that was so, the policy could be challenged only by judicial review proceedings. ${ }^{144}$

Finally, it should be noted that, given the limitations set by section 49 of the Family Proceedings Act 1980, there are obvious difficulties in identifying the parent of a child over the age of six "in law". ${ }^{145}$ These are outside the scope of this discussion.

\section{Sexual Violation or Incest}

The remaining exception is that arising from sexual violation or incest. An immediate problem is then the well-recognised reluctance of survivors to disclose the event except under closely controlled conditions. ${ }^{146}$ Where such an allegation is made, MSD staff are instructed neither to require proof by way of police reports nor to require "unnecessary detail". ${ }^{147}$ In SSAA Decision No 039/03, the Appeal Authority held that: ${ }^{148}$

Where the Chief Executive is satisfied that a beneficiary falls within the [sexual violation] exception and there has been a delay in the disclosure of the information which has led to the exception being established in our view the Chief Executive should consider under the provisions of section 81 [which gives the chief executive the power to review the rate of any benefit previously paid to a beneficiary] whether or not the beneficiary should have been paid a benefit at the full rate without deduction from the time of application or whether deduction should be lifted only from the time the Chief Executive is satisfied that one of the exemptions applies. Such a consideration would involve taking into account a number of different factors including the reasons why the appellant did not disclose the nature of the child's conception at an earlier stage, and the length of the delay in making the disclosure.

144 There are a number of historical examples of challenges on this basis. See for example, Ankers $v$ AttorneyGeneral [1995] 2 NZLR 595 (HC). It remains a complex and arguably unsatisfactory remedy in the usually pressing circumstances of most social security cases.

145 One answer, although a highly technical one, is an application for a declaration of paternity under section 10 of the Status of Children Act 1969. See generally Webb and others, above n 116, para 6.513; Trapski and others, above 116, (vol 5) "Paternity".

146 The literature on reluctance to report and/or disclose is extensive. For a New Zealand survey, see Jan Jordan "Women, Rape and the Reporting Process", in Juliet Broadmore, Coral Shaw and Tania Warburton (eds) Rape: Ten Years On: Proceedings of an Inter-Disciplinary Conference (Doctors for Sexual Abuse Care, Wellington, 1996).

147 For the relevant operational guideline relating to this exception, see also n 133, para 30.

148 SSAA Decision No 039/03, above n 134. 
Assuming that section 81 of the 1964 Act can be used in this way, ${ }^{149}$ the approach of the Authority in applying that analysis to the facts gives little scope for believing that many applicants will benefit from it. In the case in question, the appellant had been raped and had not realised that she was pregnant until it was too late for an abortion. The father (who was imprisoned for armed robbery at the time of the child's birth) had a history of violence and had subsequently harassed the appellant and her children, leading to protection orders and a number of stays in a women's refuge. She had been too fearful to take steps to identify him as the father "in law" and had not disclosed the sexual violation. Eventually, almost ten years after the deductions commenced, a lawyer wrote to the Department noting that there would be difficulty in instituting paternity proceedings and the deduction was eventually removed from the date of that letter. The Appeal Authority dismissed an appeal against the earlier deductions and ruled out the use of section 81 in this case. The Authority's reasoning was that the appellant was aware of the relevant law, the delay was "unusually lengthy" and the appellant had had the opportunity to disclose the sexual violation to the Department on a number of occasions. It is suggested that this approach manifestly overlooks the nuances of disclosure in such cases, particularly in its reference to an implied anomaly arising from disclosure to the appellant's lawyer yet continuing non-disclosure to the Department.

\section{Risk of Violence not Currently a Ground for Exemption}

There is currently no exemption under section $70 \mathrm{~A}$ on the ground that identifying the other parent will lead to a risk of violence to the mother or to her child or children. This issue arises repeatedly in practice and initially clouded the application in SSAA Decision No 039/03, ${ }^{150}$ since the applicant's case for not identifying the father "in law" had originally been presented to the Department as arising from fear of the consequences for her and her family. Under existing operational guidelines, ${ }^{151}$ beneficiaries who have genuine concerns about violence from the other parent if a child is included in their benefit are simply to be advised that information contained in their benefit record is confidential and that - while failure to apply for child support will result in a reduction in their benefit rate - they can still include the child in their benefit. Concerns about the welfare of the child are to be referred to the Department of Child, Youth and Family Services. At the very least, the continuing application of the reduction to women who fail to identify fathers on this basis has been difficult to reconcile with the recognition - in other policy areas - of the

149 Such an approach would seem not to offend the High Court's analysis that section 81 of the Social Security Act 1964 cannot be employed retrospectively so as to substitute one benefit for another, see Moody $v$ Chief Executive, Department of Work and Income, above n 110, applied in Chief Executive, Department of Work and Income $v$ Vicary [2001] NZAR 628 (HC), since the issue is the rate of a benefit already granted. See generally "Social Security Law", above n 36; Black, Harrop and Hughes, above n 11; and The Laws of New Zealand Social Security, above n 36.

150 SSAA Decision No 039/03, above n 134

151 See $n 38$ 
impact of violence on the relevant statutory criteria. ${ }^{152}$ As we will see below, that legislative gap is about to be remedied by provisions in the Social Security (Social Assistance) Amendment Bill 2004.

\section{E Availability of Ameliorative Entitlements}

The extent to which the reduction under section 70A can then be compensated by other forms of social security support remains open to argument. Under section $61 \mathrm{G}$ of the 1964 Act, a "supplementary" special benefit is available to "top up" core social security benefits, at the chief executive's discretion, on grounds of a continuing deficiency between income and essential expenditure. In SSAA Decision No 89/95, ${ }^{153}$ the Appeal Authority ameliorated the effect of section $70 \mathrm{~A}$ by allowing the mother of children, whose father had not been identified for fear of violent retribution, to qualify for a special benefit to meet some of the resulting shortfall when a reduction had been imposed. The Department had relied on instructions in the relevant internal policy manual by using the full notional rate of the DPB as the "core benefit" figure when assessing the income deficiency for special benefit purposes, notwithstanding that the appellant's benefit was in fact reduced by $\$ 44$ a week ( $\$ 22$ a week each for two dependent children). On applying the "theoretical" full notional rate of benefit, rather than the actual amount received, she had then been found not to qualify for the special benefit. By the time of the hearing, the appellant had three dependent children whose father had not been named and $\$ 88$ per week was being deducted. ${ }^{154}$ Whilst the Department argued that Parliament could not have intended the reductions under section 70A to be "nullified" by the provisions of section $61 \mathrm{G}$, and the Appeal Authority agreed that the incentive in section 70A should not be "lost". The Authority held that it was "not reasonable to expect a person with three children to care for and support to survive on $\$ 88$ or even $\$ 66$ less per week than another in a similar position". ${ }^{155}$ This was said to be particularly so where

152 The Court of Appeal accepted in Ruka v Department of Social Welfare, above n 63, that violence towards the woman may be one indicator that no relationship in the nature of marriage exists. Further, under existing policy, the usual two week stand down before entitlement to a benefit (including a DPB) commences, see section 80 of the Social Security Act 1969, is not applied where the woman concerned has entered a women's refuge. Special needs grants under section 124 of the Social Security Act can be paid to solo parents without resources who are escaping violence and who are being assisted in relocation. See the operational guidelines, above n 38 , under "Special Needs Grants".

153 SSAA Decision No 89/95 (8 August 1995) SSA 55/95.

154 It was unclear from the evidence before the Appeal Authority whether this also included deduction for debts owing to the Department as well.

155 The MSD's operational policy, above n 38, does not address this issue directly, but states under "Special Benefit" that one consideration in deciding whether to grant a special benefit is the "extent to which the basic necessities of life for the client and any dependant would be at risk if the Special Benefit was not granted or [the benefit] was paid at another rate". In this context, this guideline might be taken to outweigh other guidelines which state that consideration could be given to declining (or reducing) the special benefit where the client has refused to access alternative sources of assistance [in this case, by identifying the father "in law"). 
the appellant had been threatened with violence and had suffered extreme financial hardship (in this case for over a year) so that "these threats [were] sufficiently real to her that they [provided] a more powerful incentive than the financial incentive in section $70 \mathrm{~A}$ to name the other parent". Although the Authority suggested obiter that a deduction might properly have been made for one child, and special benefit still calculated at the full rate, in SSAA Decision No 031/02, ${ }^{156}$ an appellant, who had been paid the DPB with a reduction for one child whose father was not named, was noted as having then received the special benefit because of the resulting shortfall in her budget. ${ }^{157}$

Whilst the result in these decisions may appear to be inconsistent with the approach under which emergency benefit is almost certainly unavailable for those unmarried women beneath the age of 16 , to prevent circumvention of the minimum age limit, ${ }^{158}$ the issues may be distinguished on the basis of the underlying purpose of each benefit. In addition, the Appeal Authority's approach is consistent with the statutory scheme under which, historically, express provision has been made in cases where Parliament intended to exclude access to supplementary benefits by way of reinforcing other sanctions. ${ }^{159}$

Since the special benefit may be limited in time, ${ }^{160}$ it was suggested by the Appeal Authority, in an earlier decision involving the effect of violence on eligibility per se, that supplementary assistance might be utilised for a time-limited period to enable some resolution to be reached on the failure to name, through specialist intervention. ${ }^{161} \mathrm{~A}$ tidier solution, of course, and one that was repeatedly raised in this context, was to amend the legislation to provide a further exception to the duty to identify the father. Successive governments declined to adopt this option, ${ }^{162}$ until the introduction of the Social Security (Social Assistance) Bill 2004, to which we may briefly turn.

156 SSAA Decision No 031/02 (23 April 2002) SSA 172/01.

157 Although the rate and mode of calculation remained unspecified.

158 See n 38

159 Such as "work test failure" or loss of employment due to misconduct, both of which excluded access to the special benefit (amongst other things) under now-repealed provisions.

160 Office of the Minister of Social Services Work and Income, Ministerial Direction "Special Benefit" (10 February 1999) as amended paras 5.1 and 5.2, see Social Security Act 1964, s 5. See Also Stemson v Director-General of Social Welfare (28 June 2000) HC AK AP23-SW00; Nicholl v Chief Executive, Department of Work and Income (6 March 2001) HC WN AP 20/99.

161 SSAA Decision No 120/93 (15 December 1993) SSA 28/93, a pre-Ruka decision relating to the effect of violence on eligibility under section 63(b) of the Social Security Act 1964.

162 In 2002, for example, a number of submissions on the Social Security (Working Towards Employment) Amendment Bill 2001, no 178-1, raised the issue, without response from the select committee, in the context of changes to the DPB under that Bill. 


\section{F The Social Security (Social Assistance) Bill 2004}

The failure of some sole parent beneficiaries to legally identify the other parent of their child, or their refusal to apply for child support, has been a regular feature of political controversy and one that enjoys seemingly undiminished media appeal. ${ }^{163}$ As the Explanatory note to the bill puts it: 164

A growing number of liable parents are failing to meet their financial responsibilities to their children. This in turn creates a financial inequity between the parents in respect of the costs of supporting their children, reduces the child support revenue the State receives to help offset the costs of paying sole parent benefits, makes it financially harder for the custodial parent to move off benefit as that parent would not receive child support, and may cause financial disadvantage to their children.

As a response, the Government proposes to increase the current $\$ 22$ reduction in benefit for continuing failure to meet the requirements of section $70 \mathrm{~A},{ }^{165}$ once the beneficiary has been given what the bill describes as "a reasonable opportunity to reconsider their decision". ${ }^{166}$ It is proposed that an additional reduction of $\$ 6$ per week per child will be applied on or after 1 July 2005, where three months have passed since the $\$ 22$ reduction was imposed and the failure continues. It will continue to apply until the beneficiary has met the requirements of section $70 \mathrm{~A}$ for all dependent children. ${ }^{167}$ The "opportunity to reconsider" is envisaged as taking the form of information through correspondence and an early intervention programme involving a home visit by MSD field officers. ${ }^{168}$

These new penalties, when aligned with other Government measures such as the wellpublicised "Jobs Jolt" package, ${ }^{169}$ have been seen as resulting from a desire to reduce electoral traction for right of centre opposition parties when seeking support from those who view

163 The number has increased from 7,965, or 5.6\% of all sole parents in 1993 to 19,467 , or $16 \%$, in 2004: Social Security (Social Assistance) Amendment Bill 2004, no 193-1, Explanatory note, 2.

164 Social Security (Social Assistance) Amendment Bill 2004, no 193-1, Explanatory Note, 2.

165 Now redefined in a new proposed paragraph (c) to section 70A(1) of the Social Security Act 1964: Social Security (Social Assistance) Amendment Bill 2004, no 193-1, cl 7.

166 Social Security (Social Assistance) Amendment Bill 2004, no 193-1, cl 3.

167 Social Security (Social Assistance) Amendment Bill 2004, cl 7, which repeals the current subsection (4) of section 70A of the Social Security Act 1964 and substituting new subsections (4)-(8).

168 Social Security (Social Assistance) Amendment Bill 2004, no 193-1, Explanatory note, 3. When the Bill was reported back, the Social Services Committee recommended that clause 7 should come into effect on the day after the Bill received the Royal assent, so as to give beneficiaries "reasonable time to reconsider" before July 2005, but otherwise recommended no change to the provision. Social Security (Social Assistance) Amendment Bill 2004, no 193-2 (the commentary) 2-3.

169 See John Hughes "Jolt and Jive" [2003] ELB 73. 
beneficiaries in a negative light. ${ }^{170}$ They are balanced, however, by the introduction of two further exemptions from liability for the reduction. First, a benefit will not be reduced if the chief executive is satisfied that the beneficiary or any of the beneficiary's children would be at risk of violence if she or he complied with any of the relevant requirements. ${ }^{171}$ "Violence" carries the same meaning in this context as in section 3 of the Domestic Violence Act 1995, namely physical abuse, sexual abuse and psychological abuse (including intimidation, harassment, damage to property, and threats of such abuse). ${ }^{172}$ It is not clear who is intended to make this risk assessment, which will often call for some specialised knowledge well beyond that likely to be held by the MSD's case managers. ${ }^{173}$ Second, no reduction will apply if there are compelling circumstances and there is no real likelihood of child support being collected from the other parent (or their estate) for the foreseeable future. ${ }^{174}$ This is designed as a default option, where it is clear that a sole parent beneficiary's circumstances are such that no reduction should be imposed, notwithstanding that they do not fall within the existing exemptions: ${ }^{175}$

Compelling circumstances under which the new exemption could apply include-

- $\quad$ refugees and asylum seekers where the other parent(s) of the child is overseas, missing, or deceased:

- where the other parent of the child is deceased:

- $\quad$ carers of children not their own where the natural mother has not established paternity.

170 For differing responses to the Bill, albeit advancing this same analysis, see the first reading speeches of Sue Bradford, for the Green Party, and Katherine Rich, for the National Party, at (15 October 2004) 620 NZPD 15809 and 15805 respectively.

171 Social Security (Social Assistance) Amendment Bill 2004, no 193-1, cl 7 proposing to insert a new para (ba) to section 70A(3) of the Social Security Act 1964.

172 Social Security (Social Assistance) Amendment Bill 2004, no 193-1, cl 7, proposing to insert a new subsection (9) in section 70A of the Social Security Act 1964.

173 Presumably for this reason, as noted at note 133 above, case managers are advised not to insist on "unnecessary details" when dealing with the incest or sexual violation exemption. Two analogies exist under the of the Social Security Act 1964. First, there is the mandatory involvement of a professional agency where an unmarried mother aged 16 or 17 applies for an emergency maintenance allowance under section 61 on the ground that it is unreasonable for her to live with her parents, amongst other things because of the risk of violence (see note 41 , above). Second, assessment of whether there has been a family breakdown under section 60F, for purposes of entitlement to an independent youth benefit for a 16 or 17 year old, is an issue that again often involves family violence. The MSD relies on a preliminary assessment by psychologists employed by the Specialist Education Services (SES). This interviewing is then contracted out under a Memorandum of Understanding between the MSD and the SES.

174 Social Security (Social Assistance) Amendment Bill 2004, no 193-1, proposing to insert a new para (bb) into subsection (3) of section 70A of the Social Security Act 1964.

175 Social Security (Social Assistance) Amendment Bill 2004, no 193-1, explanatory note, 4. 


\section{EFFECT OF CUSTODY}

Since 1991, in most circumstances, only one parent can qualify for the DPB. The rationale is that parents are expected to arrange custody so that one of them can obtain paid work. ${ }^{176} \mathrm{Custody}$ arrangements between parents are generally divided into either "split" or "shared" custody. ${ }^{177}$

Split custody arises where parents are living apart and each parent has care of at least one child of the relationship. ${ }^{178}$ Under section 27BA(1) of the 1964 Act, where parents of two or more dependent children are living apart and each parent is the principal caregiver of one or more of the children, only one parent is entitled to a DPB in respect of the children. This is so even if both parents would otherwise be entitled, notionally, to the benefit.

Subsection (2) of section 27BA then sets out a priority order which is used in determining which parent is entitled to the DPB. First, if one parent already receives a DPB in respect of any of the children, it will continue to be paid. The other parent will not be eligible. Next, if both parents apply at the same time, the parent whom the chief executive considers was the principal caregiver immediately before the separation will be entitled to the DPB. "Principal caregiver" is defined as the person who in the opinion of the chief executive had primary responsibility for day to day care of the child, other than on a temporary basis. ${ }^{179}$ For this purpose, for example, a custodial parent whose child is away on holiday with the non-custodial parent has been held to retain primary responsibility for the child during the holiday period. ${ }^{180}$ Finally, if neither parent was the principal caregiver before they began living apart, or the chief executive is unable to ascertain which parent fulfilled this role, then the parent who has custody of the youngest child is entitled to the DPB. As

176 For custody, see Webb and others, above n 116, paras 6.101-6.142 and the research cited there; Trapski and others, above n 116, (vol 4) "Custody".

177 See for custody, see Webb and others, above n 116, paras 6.101-6.142 and the research cited there; Trapski and others, above n 116, (vol 4) "Custody". See also Georgie Hall and Angela Lee Family Court Custody and Access (Department of Justice, Wellington, 1994); Stuart Birks (ed) Childrens' Rights and Families: Proceedings of a Social Policy Forum (Centre for Public Policy Evaluation, Massey University, Palmerston North, 2001); Anne B Smith and others Children Whose Parents Live Apart: Family and Legal Concepts (Children's Issues Centre, University of Otago, Dunedin, 2001). Possible reforms are outlined in Ministry of Justice Responsibilities for Children (Ministry of Justice, Wellington, 2000).

178 Meaning a child born or adopted into the union: Social Security Act 1964, s 27BA(5). Split custody has a particular place within Maori cultural practice following separation between parents. See Hall and Lee, above $n$ 175,74 .

179 Social Security Act 1964, s 3. The definition excludes any incorporated or unincorporated body or the proprietors of various institutions in which a child might be cared for.

180 SSAA Decision No 044/02, above n 56. The Authority noted that the custodial parent will "inevitably have ongoing costs relating to the maintenance of the child such as accommodation costs and must continue to plan a budget for other ongoing child related expenses regardless of whether the child is in the custodial parent's actual physical care". 
the Appeal Authority once put it, "[the] provisions of section 27BA(1) and (2) are clearly designed to encourage separated parents to organise their families in such a way that only one parent can be paid [a DPB]". ${ }^{181}$

The only exception, arising under subs (3) of section 27BA, is where each of the parents "has become" the principal caregiver in respect of at least one child pursuant to "split" custody under a court order. In this case both parents may receive a DPB. This recognises the reality of split custody as an effective form of day-to-day "sole" custody of a child. ${ }^{182}$ Such an order is rare, however, and the exception does not apply to the far more common custody agreements which have been registered in the Court. When an appellant and his wife had an informal agreement as to split custody, but then obtained court custody orders in order to attempt to assist in qualifying for a DPB, the Appeal Authority held that subsection (3) was directed rather to the situation where: ${ }^{183}$

[The] parents have been unable to agree on custody arrangements in relation to their children and after a defended hearing a family court has ruled that custody of the children should be split between the parties and as a result each parent becomes the principal caregiver in respect of at least one child ... The words of the section require each parent to become the principle caregiver as a result of the court order being made. In our view any other interpretation would negate the intention in section 27BA ss (1) and (2) that generally speaking only one Domestic Purposes Benefit should be paid other than in what is the relatively unusual circumstances of a court determining that the custody of the children should be split.

In the absence of such a court order, in split custody cases the other parent may apply for another social security benefit and have their child(ren) included in that other benefit, but they must meet all the criteria for payment of that benefit (for example, the "work test" in the case of an unemployment benefit). In addition, the other benefit will be paid at a less generous rate than the DPB. ${ }^{184}$

Shared custody arises where the parents take the child(ren) "turn and turn about". In the words of section 70B of the 1964 Act, the parents of a dependent child are living apart, they are both beneficiaries and each has the "primary responsibility for the care of that child" for at least 40 per cent of the time. ${ }^{185}$ Under section $70 \mathrm{~B}(1)$, only one parent is eligible to have that child taken into

181 SSAA Decision No 023/03 (17 March 2003) SSA 236/02.

182 See Hall and Lee, above n 177, 75.

183 SSAA Decision No 023/03, above n 179 (emphasis added).

184 See Ministerial Task Force on Income Maintenance, above n 74

185 Under section 12 of the Child Support Act 1991, resolution under section 70B of the Social Security Act 1964 then operates as a guideline for purposes of the 1991 Act. The correlation between the two provisions for child support purposes is outside the scope of this article. See Webb and others, above n 116, para S.208; Trapski and others, above n 116, (vol 5) "Child Support". 
account for assessing entitlement to any benefit and for fixing the rate of that benefit. This is the parent whom the chief executive determines has the greater responsibility for care of the child(ren). ${ }^{186}$ In deciding who has the greater responsibility, under subsection (2) the chief executive has to have regard primarily to the periods the child is in the care of each parent and then to the following factors:

(a) How the responsibility for decisions about the daily activities of the child is shared;

(b) Who is responsible for taking the child to and from school and supervising the child's leisure activities;

(c) How decisions about the education or health care of the child are made;

(d) The financial arrangements for the child's material support;

(e) Which parent pays for which expenses of the child.

In considering "the periods the child is in the care of each parent" under subsection (2), the Appeal Authority has adopted conflicting approaches. In SSAA Decision No 167/01, ${ }^{187}$ the Authority held that the phrase must relate to the term "primary responsibility for the care of that child" under subsection (1). In that case, one parent had primary responsibility for the child during periods when he was in school, during which time she was the principal contact person and decision-maker on educational matters. On this basis, the Authority attached no significance to the fact that the child was actually at school for part of the time during which the parent was primarily responsible for care. Against this, in a later decision, the Authority focused on the time actually spent with each parent as opposed to the time period for which each parent was notionally responsible for the child. In SSAA Decision No 009/03, ${ }^{188}$ the respective hours of notional responsibility favoured the mother, but the weekday period during which she was responsible for care included a significant element of school time. The father (who cared for the children from Thursday morning until Sunday evening) was held to have had greater responsibility "in terms of direct contact" and to then qualify for the DPB. It is suggested that the former approach is to be preferred, since the legislation refers to responsibility for "care", and reading this to mean "direct contact" arguably places a gloss on the plain statutory wording.

If the chief executive is unable to ascertain that one parent has the greater responsibility using these criteria, then only the parent whom the chief executive ascertains to have been the principal

186 Before October 1991, under Departmental guidelines, both parents could receive a DPB if they shared custody of a child for an average of three nights per week each, although the Social Security Appeal Authority had questioned whether this approach was consistent with the legislation: SSAA Decision No 14/92 (19 January 1992) SSA 61/90.

187 SSAA Decision No 167/01 (14 November 2001) SSA 147/01.

188 SSAA Decision No 009/03 (14 February 2003) SSA 078/02. 
caregiver immediately before the parents began living apart is entitled to have the child taken into account in assessing entitlement to a benefit and the rate of benefit payable. ${ }^{189}$ The only questions relate to the respective roles the parties had while they were living together - who had the greater responsibility or was principal caregiver ${ }^{190}$ If, in turn, this cannot be ascertained, the parents must agree between themselves as to which of them may have the child taken into account. By way of a blunt incentive to reach agreement, until that agreement is reached neither can qualify as having the child taken into account. ${ }^{191}$ Nevertheless, the Appeal Authority has suggested that, in shared custody situations, applications should be handled in a manner which does not exacerbate tensions between the parties and that it might be appropriate "that a person who is not the case manager of either applicant, interviews each person independently and reaches a conclusion as to who is the person with primary responsibility for the children concerned". 192

Where one parent is granted a DPB as the result of a decision under section $70 \mathrm{~B}$, the other parent may qualify for another benefit but only at the single rate and the child will not be included in the rate of that other benefit. ${ }^{193}$ The operational instructions then probably operate as a fetter on the discretion to grant an emergency benefit under section 61 in stating that emergency benefit cannot be paid at all to the other parent on the basis of part-time care for the qualifying child. ${ }^{194}$ The Appeal Authority has suggested, however, that "given the clear indication in section 70B that the children should be included only in the benefit of one parent in shared custody situations" it would not consider it appropriate to include children - even in an assessment of an emergency benefit granted to the other partner and based on hardship - in the absence of "special or unusual circumstances". 195

189 Section 70B(3) of the Social Security Act 1964. This does not extend to any question of apportionment where a child disability allowance under section 39E of the Social Security Act 1964 is involved, even though that allowance also uses the term "principal caregiver": SSAA Decision No 055/03 (17 April 2003) SSA 65/02.

190 SSAA Decision 106/92 (23 September 1992) SSA 65/92; SSAA Decision No 44/95 (19 June 1995) SSA 65/94. For an example of the application of this provision where differences between existing responsibilities were "marginal", see SSAA Decision No 167/01, above n 187. In the context of a volatile relationship, marked by frequent separations, the fact that the appellant did not care for the children during periods of separation (other than for holidays or access weekends) was held to point to his partner having primary care during the period in question; SSAA Decision No 074/2004 (23 June 2004) SSA 219/03.

191 In SSAA Decision No 33/94, above n 119, a benefits review committee was held not to have followed section $70 \mathrm{~B}$ when it referred the matter back to the parties without determining who had been the principal caregiver when they began to live apart.

192 SSAA Decision No 009/03, above n 188. For an illustration of such tensions being generated by the provision see for example SSAA Decision No 13/02, (15 March 2002) SSA 171/01.

193 SSAA Decision No 44/95 (19 June 1994) SSA 65/94.

194 For the guidelines, see $\mathrm{n} 38$.

195 SSAA Decision No 009/03, above n 188. 
Rigidly applied so as to extend to "safety net" provisions - and the case law suggests that it is often so applied - this analysis might obviously affect contact which the children have with separated parents who are both beneficiaries. ${ }^{196}$ For example, in SSAA Decision No 106/92, ${ }^{197}$ the appellant, whose partner qualified under section 70B, could not afford to feed the children whilst they were with him. Nevertheless, in subsequent decisions, the Authority has expressed "some sympathy for the proposition that assistance needs to be given to beneficiaries to meet the basic costs relating to access", 198 including entitlement to a "supplementary" special benefit under section $61 \mathrm{G}$ of the 1964 Act, on grounds of hardship. ${ }^{199}$ In SSAA Decision No 045/03, ${ }^{200}$ the Appeal Authority rejected a submission from the chief executive that section 70B precludes the chief executive from taking access costs into account in assessing entitlement to a special benefit.

$\boldsymbol{X}$

WORK TEST

The work-testing approach introduced in 1997, and outlined above, was abandoned following a critical analysis of its operation. ${ }^{201}$ Under that analysis, work-testing was seen to embody several key weaknesses. ${ }^{202}$ The most significant aspect of the change was described as being a shift from a

196 For the family policy implications of such restricted contact, see Hall and Lee, above n 177; Birks, above n 177; Smith and others, above 177.

197 SSAA Decision 106/92, above n 190.

198 SSAA Decision No 68/02 (13 June 2002) SSA 003/02. In this case, however, the Authority declined to award such assistance on the basis that the appellant had not taken "responsible steps to ensure that he can balance his budget".

199 SSAA Decision No 106/99 (19 October 1999) SSA 110/99; SSAA Decision No 040/02 (29 April 2002) SSA 135/01; SSAA Decision No 070/03 (29 May 2003) SSA 127/02; SSAA Decision No 087/03 (26 June 2003) SSA 251/02; SSAA Decision No 045/03 (15 April 2003) SSA 097/02. The measure adopted by the Appeal Authority in assessing food costs for purposes of the special benefit is the Estimated Food Costs Survey 2002 conducted by the Department of Human Nutrition, University of Otago, which applies a graduated scale depending on the age of the child, see SSAA Decision No 040/02 (29 April 2002) SSA 135/01; SSAA No 050/02 (21 May 2002) SSA 004/02. The standard costs formula provided in the Ministerial Directive on special benefit, above n 158, makes no allowance between differing costs in feeding and clothing children at different ages, or in different areas of the country. Limited provision for differences in the number and age of children is made through family support payments.

200 SSAA Decision No 045/03, above n 199.

201 Ministry of Social Development "Evaluating the February 1999 Domestic Purposes Benefit and Widows Benefit Reforms" in Documents on DPB/WB Reform (Ministry of Social Development, Wellington, 2001).

202 For example, a failure to take into account broader issues than the age of dependent children that might be acting as a barrier to participation in training employment; not fully taking into account family responsibilities or individual circumstances; and not sufficiently supporting those who were not yet work-tested to progress towards work if they chose to do so, see Office of the Minister of Social Services and Employment "Paper to the Cabinet Social Equity Committee: Social Assistance Initiatives: Paper C" (7 November 2002) SEQ(01)124, para 6. See also The New Zealand Government Pathways to Opportunity (The New Zealand Government, Wellington, 2001) 
status-based approach, tied to the age of the youngest child, to a needs-based approach, tied to "assistance tailored to individual strengths and needs as well as taking into account family responsibilities". 203

In essence, the work-test obligations for recipients of the DPB were replaced with an enhanced case management model, aimed at promoting "goal setting and planning" linked to preparation for employment "when circumstances make this appropriate". ${ }^{204}$ In place of the work-test, under section 27(2A) of the 1964 Act, a person receiving a DPB as a solo parent must comply with a range of obligations with the stated objects of facilitating the movement of beneficiaries into continuing employment "as their parenting responsibilities and individual circumstances allow", providing opportunities to improve capability for employment and improving social and economic outcomes for those beneficiaries and their dependent children. ${ }^{205}$ Under the new provisions, recipients of a DPB are required to attend interviews so as to participate in a planning process designed to support the move from benefit to work. The process is essentially designed to identify constraints on obtaining and sustaining employment arising from the person's individual circumstances or parenting responsibilities. ${ }^{206} \mathrm{~A}$ failure without good and sufficient reason to cooperate in the prompt development of what is then termed a "personal development and employment plan", or a failure to demonstrate commitment to the plan on an annual review, may lead to reduction of the benefit as a sanction. ${ }^{207} \mathrm{~A}$ benefit that has been reduced by a sanction may then be increased to the full rate and backdated to the date the reduction took place, as soon as the beneficiary concerned agrees to comply with the relevant requirement. ${ }^{208}$

Many submissions on the Bill opposed the generally compulsory requirements and associated sanctions, particularly because the criteria for the imposition of sanctions are vaguely defined. ${ }^{209}$

203 Office of the Minister of Social Services and Employment, above n 202, para 7. One aspect of such assistance is the training incentive allowance programme under section 124(1)(d) of the Social Security Act 1964, directed to those receiving a DPB, or related emergency benefit, an invalid's benefit or a widow's benefit. For consideration of the scope of this programme, see SSAA Decision No 144/02 (20 November 2002) SSA 105/02; SSAA Decision No 148/02 (20 November 2002) SSA 113/02.

204 Social Security (Working towards Employment) Amendment Bill 2002, no 178-2, as reported from the Social Services Committee (the commentary) 1.

205 Social Security Act 1964, s 60P.

206 Social Security Act 1964, s 60Q.

207 Social Security Act 1964, ss 60W and 60X.

208 Social Security Act 1964, s 60Y.

209 Social Security (Working Towards Employment) Amendment Bill 2002, no 178-2, as reported from the Social Services Committee (the commentary) 4. The main criterion under section 60U of the Social Security Act is failure, without "good and sufficient reason", to "demonstrate commitment" to planning requirements, with only two such reasons (failure of the MSD to provide assistance or to take action) being stated expressly. Against 
In response, the majority of the Select Committee argued simply that "an Act which contains requirements must also contain consequences for when requirements are not met". ${ }^{210}$ The new provisions, which were coupled with a change to the abatement regime allowing solo parents to retain more earned income, have attracted no case law.

\section{CONCLUSION}

The potential for the administration of the DPB to intersect with broader issues of family policy is reflected in a number of respects. The reduction in the rate of the benefit for failure to identify the father of the child, which is not applied in some overseas jurisdictions, ${ }^{211}$ has been described by one commentator as having "more in common with the New Poor Law in nineteenth century Britain than any of the benefits introduced by the 1938 Social Security Act". ${ }^{212}$ The past failure to make any exception where the non-identification arises from fear of violent retribution has clear implications, in terms of family policy, for both mother and child(ren). The proposed closure of this legislative gap is long overdue. ${ }^{213}$ The need to consider the role of social security support within a violent relationship is further highlighted by the general absence of consideration of "notional entitlement" in the relevant case law, despite operational guidelines providing for the possibility of entitlement. ${ }^{214}$

Other issues where family policy intersects with the operation of the DPB include the factors which are used to establish an initial inference of a relationship in the nature of marriage, or whether married people are "living apart", which include the sharing of childcare responsibilities. ${ }^{215}$ The inevitable tensions created in those cases where a contest arises between the parents for eligibility for the benefit, either before, during, or after a custody dispute, serve as another example. ${ }^{216}$ Furthermore, a number of Appeal Authority decisions over the past decade, ${ }^{217}$

this, the National Party and ACT Party minority views to the select committee's commentary opposed the repeal of work-testing (at pp 11-12).

210 Social Security (Working Towards Employment) Amendment Bill 2002, no 178-2, as reported from the Social Services Committee (the commentary).

211 These are Scandinavian and Germanic countries, with New Zealand and the United States of America alike applying reductions for failure to identify. See Robert Stephens "The Level of Financial Assistance to Families with Dependent Children: A Comparative Analysis" (2003) 20 Social Policy Journal of NZ 173, 187.

212 Goodger, above $\mathrm{n} 1,135$.

213 See $n 160$

214 See n 110

215 See n 102.

216 See n 190

217 See n 197. 
indicate that the MSD and its predecessors have regularly ignored the Authority's view that where appropriate - the special benefit should be calculated so as to facilitate access to children by non-custodial parents. ${ }^{218}$ In these instances, even if the current legislative structure is accepted, it would seem desirable to ensure that the Ministry's operational guidelines are consistent with such broader social policy goals and formulated with appropriate consideration of wider family policy issues.

Structurally, ${ }^{219}$ of course, the domestic purposes benefit for solo parents is very much a child of its time. The need which prompted the introduction of the statutory benefit remains, however, and - in the eyes of some - in exacerbated form. As we have seen, in 1972 the McCarthy Commission had found that solo parents faced a high risk of poverty. A report in 2003 estimated that more than 60 per cent of children in households with one income live below the poverty threshold and that lone parents are particularly affected. ${ }^{220}$ Criticisms of the benefit, of course, range from libertarian objectors who oppose any provision of social security to solo parents, ${ }^{221}$ to those who accept that the benefit is necessary but see an enhanced role for attaching conditions to eligibility (and particularly conditions as to work-testing). ${ }^{222}$

The unique characteristic of the DPB for solo parents is then that restrictive changes - whether on access to the benefit or reduction in its rate - have the potential to adversely affect the children

218 The potential impact of the intended abolition of this benefit and its replacement with a less flexible measure of temporary additional support has yet to be fully gauged, see $\mathrm{n} 40$.

219 In terms of the categories of those eligible.

220 Child Poverty Action Group Our Children: The Priority for Policy (Child Poverty Action Group, Auckland, 2003). See also Charles Waldegrave, Robert Stephens and Peter King "Assessing the Progress on Poverty Reduction" (2003) 20 Social Policy Journal of NZ 197. For specific research in relation to the DPB, amongst other things, see Deborah Ball and Moira Wilson "The Prevalence and Persistence of Low Income Among New Zealand Children" (2002) 18 Social Policy Journal of NZ 92. For varying approaches to this threshold, see Robert Stephens, Charles Waldegrave and Paul Frater "Measuring Poverty in New Zealand" (1995) 5 Social Policy Journal of NZ 88: Brian Easton "Measuring Poverty: Some Problems" (1997) 9 Social Policy Journal of NZ 171, and the response from Stephens, Waldegrave and Frater at (1997) 9 Social Policy Journal of NZ 181. For an assessment of relative poverty based on participation criteria, see Ministry of Social Development The Social Report 2004 (Ministry of Social Development, Wellington, 2004) 60-73.

221 Most prominently, perhaps, the visiting US welfare analyst Charles Murray, who famously argued as a guest of the NZ Business Roundtable that it was time to "get tough on young women and their babies" (2 June 2001) Weekend Herald Auckland, by "cutting off all [state] assistance to some segment of the population - let's say girls under 21" as a way of influencing the behaviour of young people in the future: (27 June 2001) The Dominion Wellington.

222 See the dissenting report to the Select Committee's Commentary on the Social Security (Working Towards Employment) Amendment Bill 2002, no 178-2. 
whose dependency gives rise to entitlement in the first place. ${ }^{223}$ As the current Minister of Social Services and Employment once stated, it should not be overlooked that income support in the form of the DPB "contributes towards the needs of children and towards the valuable task of childcare", and that "[where] children are involved, there is the extra concern of their well-being and healthy development. They deserve special consideration because of their vulnerability."224

\section{POSTSCRIPT}

Since this article was accepted for publication, two significant developments have occurred. First, the Relationships (Statutory References) Bill has been reported from the Justice and Electoral Select Committee, and subsequently enacted. ${ }^{225}$ The majority recommendation was that the proposed amendments to the Social Security Act 1964 relating to de facto couples, and outlined above, should be omitted. ${ }^{226}$ The reasoning underlying this recommendation was the difficulty of dealing with substantive policy, and especially the effect of Ruka v Department of Social Welfare, ${ }^{227}$ in an amending bill of this particular type. The government was left to address this issue during the two-year lead-in period to the extension of coverage to same-sex de facto couples, possibly through the developments of terms of reference for referral to the Law Commission. ${ }^{228}$

Second, and more fundamentally, in February 2005 the government announced that it planned to introduce a single "core" social security benefit in $2007-2008 .{ }^{229}$ It is intended that this single benefit will replace the domestic purposes benefit, along with other current core benefits. ${ }^{230}$ The Minister for Social Development and Employment is due to report back to Cabinet on this issue by the end of 2005 with detailed proposals for legislation to be introduced in $2006 .^{231}$

223 Even when the DPB is granted, the unmet needs of both parent and child may have such effects. See Maureen Baker and David Tippen "More Than Just Another Obstacle: Health, Domestic Purposes Beneficiaries, and the Transition to Paid Work" (2004) 21 Social Policy Journal of NZ 98 and Tim O'Donovan and Karen McMillan "An Employment Barrier: The Health Status of DPB Recipients' Children" (2004) 22 Social Policy Journal of NZ 97.

224 Hon Steve Maharey "Why We Need the DPB" (5 July 2001) The Dominion, Wellington, responding to Charles Murray, above n 219.

225 Relationships (Statutory References) Bill 2004, no 151-2.

226 Relationships (Statutory References) Bill 2004, no 151-2 (the commentary) 5.

227 Ruka v Department of Social Welfare, above $\mathrm{n} 63$

228 Relationships (Statutory References) Bill 2004, no 151-2 (the commentary) 7.

229 Ministry of Social Development “Working Towards a Single Core Benefit” (22 February 2005) Press Release.

230 Office of the Minister for Social Development "Memorandum to Cabinet Policy Committee: Extending Opportunities to Work" (2 February 2005).

231 Office of the Minister for Social Development, above n 230. 
(2005) 36 VUWLR 